\title{
Foraminiferal biodiversity associated with cold-water coral carbonate mounds and open slope of SE Rockall Bank (Irish continental margin-NE Atlantic)
}

\author{
C. Morigi ${ }^{\text {a,* }}$, A. Sabbatini ${ }^{\text {b }}$, G. Vitale ${ }^{\text {b }}$, I. Pancotti ${ }^{\text {b }}$, A.J. Gooday ${ }^{\text {c }}$, G.C.A. Duineveld ${ }^{\text {d }}$, \\ H.C. De Stigter ${ }^{\mathrm{d}}$, R. Danovaro ${ }^{\mathrm{b}}$, A. Negri ${ }^{\mathrm{b}}$ \\ a Stratigraphy Department, Geological Survey of Denmark and Greenland (GEUS), Øster Voldgade 10, DK 1350 - Copenhagen K, Denmark \\ ${ }^{\mathrm{b}}$ Department of Life and Environmental Sciences, Polytechnic University of Marche, Ancona, Italy \\ ${ }^{\mathrm{c}}$ National Oceanography Centre, Southampton, Southampton SO14 3ZH, UK \\ ${ }^{\mathrm{d}}$ Royal Netherlands Institute for Sea Research, Texel, The Netherlands
}

\section{A R T I C L E I N F O}

\section{Article history:}

Received 4 May 2011

Received in revised form

13 September 2011

Accepted 20 October 2011

Available online 30 October 2011

\section{Keywords:}

Foraminifera

Biodiversity

Cold water coral

High energy/strong currents environment

North Atlantic

\begin{abstract}
A B S T R A C T
Cold-water coral (CWC) ecosystems are hotspots of macro- and microfaunal biodiversity and provide refuge for a wide variety of deep-sea species. We investigated how the abundance and biodiversity of 'live' (Rose Bengal stained) foraminifera varies with, and is related to, the occurrence of CWC on the Rockall Bank (NE Atlantic). Qualitative and quantitative analyses were performed on 21 replicate samples from 8 deep-sea stations, including 4 stations on CWC-covered carbonate mounds at depths of 567-657 m, and 4 stations on the adjacent slope at depths of 469-1958 m where CWC were absent. This sampling strategy enabled us to demonstrate that sediments surrounding the living CWC were characterised by higher foraminiferal abundance and biodiversity than open-slope sediments from the same area. A total of 163 foraminiferal species was identified. The dominant species in CWC sediments were: Spirillina vivipara, Allogromiid sp. 1, Globocassidulina subglobosa, Adercotryma wrighti, Eponides pusillus, Ehrenbergina carinata, Planulina ariminensis, Trochammina inflata and Paratrochammina challengeri. Foraminifera were nearly absent in adjacent open slope areas subject to strong tidal currents and characterised by coarse grained deposits. We suggest that CWC create a heterogeneous three-dimensional substrate offering microhabitats to a diverse benthic foraminiferal community.
\end{abstract} (c) 2011 Elsevier Ltd. All rights reserved.

\section{Introduction}

Logachev Mounds is an area located on Rockall Bank between water depths of 550 and $900 \mathrm{~m}$. The Logachev Mounds consist of a complex of mounds with abundant cold-water corals (CWC) present on the mound summits. Living CWC lack symbiotic algae and depend on the supply of current-transported particulate organic matter and zooplankton for their nutrition. For this reason, areas with high densities of living corals are characterised by strong bottom currents (Dorschel et al., 2010). To capture the food efficiently, CWC produce tree-like branching structures supporting colonies of polyps sharing a common calcium carbonate frame. These complex three-dimensional structures provide a multitude of micro-habitats for associated faunal communities, thereby enriching local biodiversity (Freiwald et al., 2004). The OSPAR (Convention for the Protection of the Marine Environment of the North-East Atlantic)

\footnotetext{
* Corresponding author. Tel.: +45 38142727.

E-mail address: cmor@geus.dk (C. Morigi).
}

commission included CWC and carbonate mounds in the list of threatened and/or declining species and habitats to ensure their protection from human activities. In particular, the Logachev Mounds are included in the Marine Protected Area by the North East Atlantic Fisheries Commission. The study of this highly vulnerable environment is important to understand its complex relationship with deep marine biodiversity.

Although, CWC have been known to science since the 18th century, their ecological requirements have only been investigated in recent years (review by Freiwald and Roberts, 2005). Most studies dealing with CWC have focused on mega- and macrofauna (Jensen and Frederiksen, 1992; Mortensen et al., 1995), fishes (Auster, 2005) and metazoan meiofauna (Raes and Vanreusel, 2005; Bongiorni et al., 2010), whereas few have targeted foraminiferal assemblages. Cedhagen (1994) described Hyrrokkin sarcophaga (up to $6 \mathrm{~mm}$ diameter), a new genus and species of parasitic calcareous foraminifera that lives on various biogenic substrates including deep-sea corals such as Lophelia pertusa, Madrepora oculata and Primnoa resedaeformis (Freiwald and Schönfeld, 1996). Hawkes and Scott (2005) studied benthic 
foraminifera (63-500 $\mu \mathrm{m}$ fraction) attached to the deep-sea gorgonian coral $P$. resedaeformis from the Scotian Margin (Canada). They found 29 species, five of which (Cibicides lobatulus, Cribrostomoides crassimargo, Cyclogyra involvens, Discanomalina semipunctata and Rosalina sp.) occurred on all analysed coral specimens. Zibrowius and Taviani (2005) found the epibenthic calcareous foraminifera Planogypsina? ( $>2 \mathrm{~mm}$ ) living on CWC collected in the Strait of Sicily (Italy). Buhl-Mortensen and Mortensen (2005) recorded 17 species of benthic foraminifera ( $>250 \mu \mathrm{m}$ ) attached to deep-sea gorgonian corals collected in the Labrador Sea; the most common species were Discanomalina vermiculata, D. coronata, Cibicides refulgens and $C$. lobatulus. Margreth et al. (2009) studied the total (unstained) benthic foraminiferal assemblages $(>63 \mu \mathrm{m})$ from surface sediment samples collected on CWC mounds in the Porcupine Seabight and on the Rockall Bank. They identified five different benthic foraminiferal associations related to the different environmental conditions that characterised five facies, one of them being living CWC. Schönfeld et al. (2010), who studied living and dead ( $>250 \mu \mathrm{m}$ fraction) assemblages, found that foraminiferal diversity on Galway and Propeller Mounds in the Porcupine Seabight on the Irish continental margin was not higher than in the adjacent offmound area. Although these studies indicated that benthic foraminifera are abundant on CWC and in the sediment around CWC, there has been no comprehensive study of the live benthic foraminiferal assemblage (soft-shelled and hard-shelled foraminifera).

Here, we describe the abundance, diversity and taxonomic composition of the 'live' (Rose-Bengal-stained) benthic foraminiferal assemblages in an area with an exceptionally dense coverage on CWC on the SE Rockall Bank (Logachev Mounds-NE Atlantic). We compare the biodiversity in the sediment underneath living corals with that of the neighbouring open-slope sediments, both at a similar depth and across a bathymetric transect down the slope (from $500 \mathrm{~m}$ to $1900 \mathrm{~m}$ water depth). We address the following questions:

- Do CWC influence benthic foraminiferal assemblages, and if how? More specifically, does the CWC habitat promote a higher foraminiferal biodiversity?

- Are foraminiferal abundance patterns at CWC consistent with those reported for the metazoan meiofauna?

- Are some foraminiferal species typical of CWC habitat or endemic to it?

- Is the composition of the living assemblage reflected by the thanatocoenosis in this area influenced by strong bottom currents?

\section{Materials and methods}

\subsection{The study site}

The mound on which this study is focused forms part of the Logachev Mounds province, a large group of giant carbonate mounds spread out between 500 and $900 \mathrm{~m}$ depth along the SE flank of Rockall Bank (Mienis et al., 2007). Rockall Bank is located between $53^{\circ} 30^{\prime}$ and $58^{\circ} 30^{\prime} \mathrm{N}$ on the Irish continental margin, approximately $400 \mathrm{~km}$ to the west of Ireland. It is separated from the European shelf by the Rockall Trough (Fig. 1). Mounds of the Logachev group occur in clusters of several kilometres in length and width, and reach heights ranging from several tens of metres to more than $300 \mathrm{~m}$. Mound clusters are separated by gullies that are oriented perpendicular to the overall trend of the slope. The summits of the mounds are densely covered with live coral framework (Fig. 2), whereas isolated corals and coral rubble are found further down the slopes of the mounds. The flat areas in

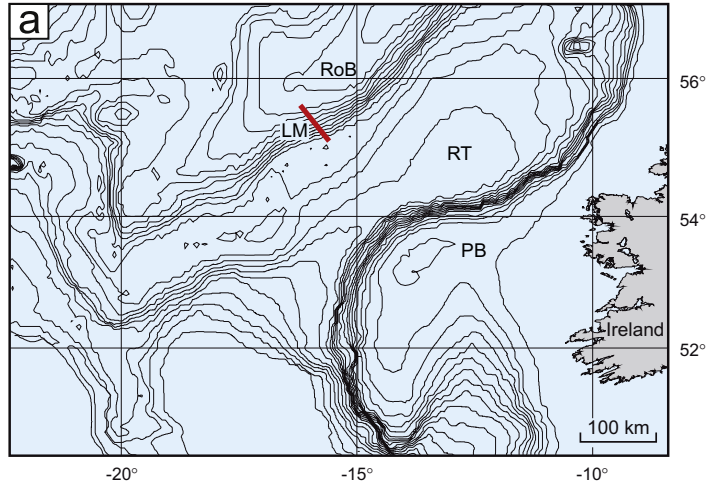

b
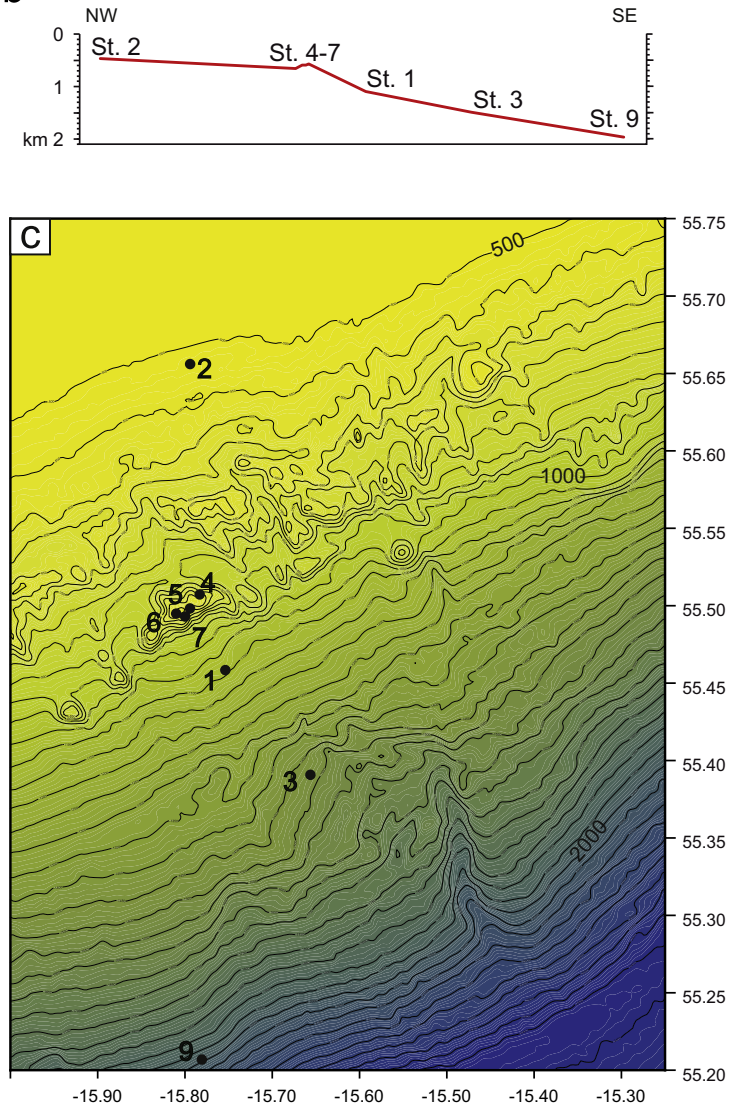

Fig. 1. (a) Map of the Irish margin showing the Rockall Bank (RoB) that hosts the Logachev Mounds province (LM), the Rockall Trough (RT) and the Porcupine Bank (PB). Contour interval is $200 \mathrm{~m}$. Bold line shows the studied area; (b) depth profile with location of the stations corresponds to the red bold line in (a); (c) location of the eight sampling sites. Contour interval is $50 \mathrm{~m}$.

between the mounds are covered with winnowed sand and pavements of ice-rafted pebbles and rocks (Fig. 2, Sts. 1 and 2), washed out from glacial sediments by strong currents. Bottomwater temperature on the Rockall Bank exhibits a daily variation of ca. $2{ }^{\circ} \mathrm{C}$, reflecting the alternation of deep, cold water flowing upslope and warmer water flowing downslope under the influence of internal tides (Duineveld et al., 2007; Mienis et al., 2007). It has been hypothesised by White et al. (2005) that enhanced surface water primary productivity over Rockall Bank is related to the formation of a cold water patch over the bank during winter (Shapiro et al., 2003). This dome of nutrient-rich and less saline water causes a spring bloom early in the year, creating locally enhanced surface productivity (White et al., 2005; Mienis et al., 2007). Sea-surface chlorophyll-a concentrations in June 2006 


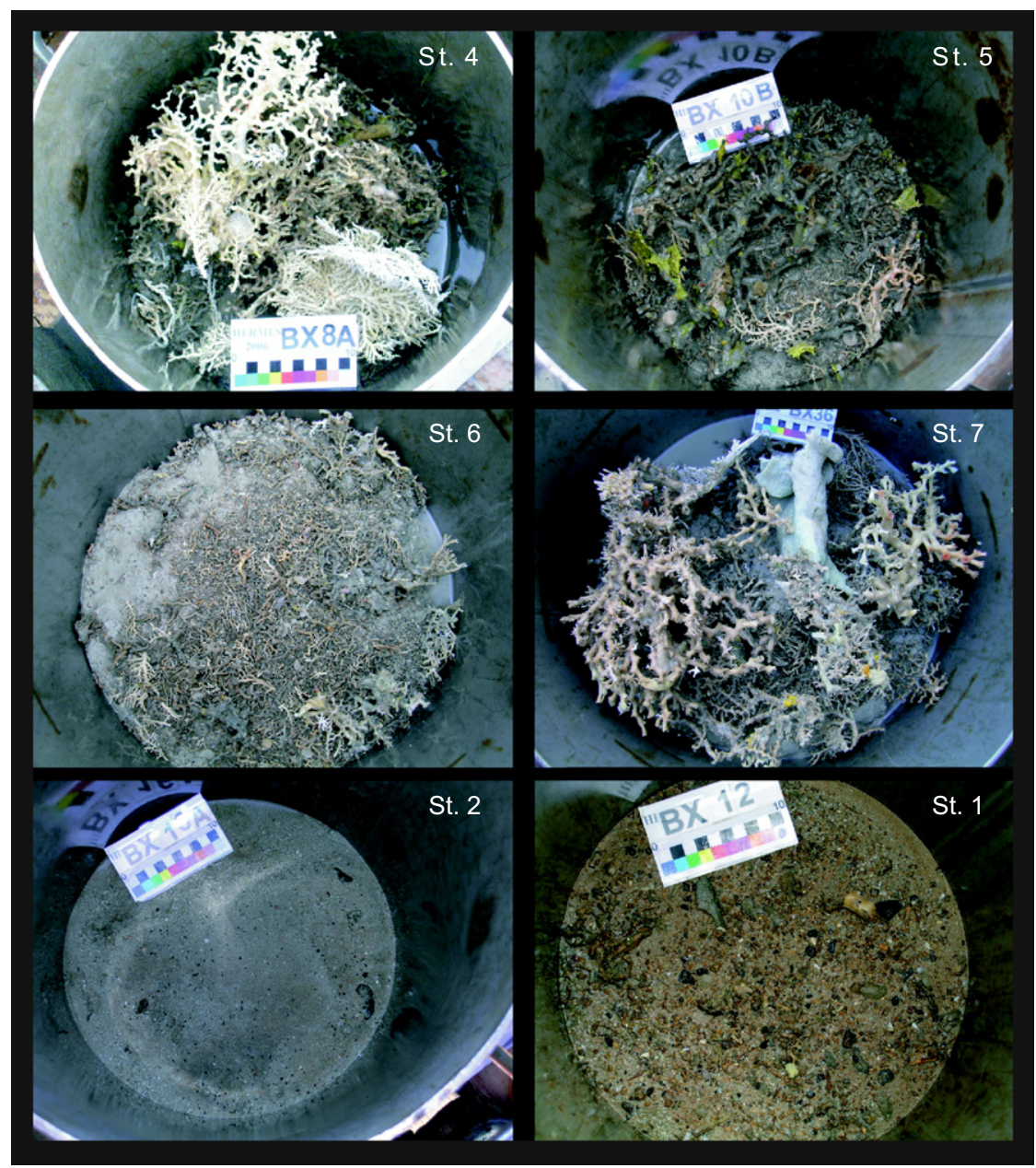

Fig. 2. Box-cores collected during the cruise 64PE249.

(during sampling time) were within the range $3-5 \mathrm{mg} \mathrm{m}^{-2}$ (http://seawifs.gsfc.nasa.gov).

Most of the samples for this study were collected on the socalled 'Haas Mounds', a relatively isolated mound cluster at the margin of the Logachev Mound province, which reaches a height of more than $300 \mathrm{~m}$ above the surrounding seabed. This cluster comprises of two relatively flat summits at $550 \mathrm{~m}$ depth, separated by shallow gullies. The summits have a dense coverage of coldwater corals, $L$. pertusa (Linnaeus, 1758) and M. oculata (Linnaeus, 1758), and sponges (Hexadella, Higginsia and Asconema).

Current speed at $1 \mathrm{~m}$ above bottom was measured with a current meter (Nortek Aquadopp) mounted on a benthic lander deployed near the top of the mound, i.e. stations 4-7. The average and maximum speeds were 9 and $30 \mathrm{~cm} \mathrm{~s}^{-1}$, respectively. Current measurements from a point immediately south of the coral mound, ca. $2 \mathrm{~nm}$ north of station 1, indicated a maximum speed of $65 \mathrm{~cm} \mathrm{~s}^{-1}$ and an average speed of $16 \mathrm{~cm} \mathrm{~s}^{-1}$. These were measured during a period of 9 days (23 June-2 July 2006) at $3 \mathrm{~m}$ above the bottom by a FSI current meter. Data published in Mienis et al. (2009) indicated that at station M2005-33 $\left(55.4890^{\circ} \mathrm{N}, 16.1416^{\circ} \mathrm{W}, 557 \mathrm{~m}\right.$ water depth), located $28 \mathrm{~km} \mathrm{SW}$ of our St. 2 in an analogue setting up-slope of the carbonate mounds, current speeds were above $15 \mathrm{~cm} \mathrm{~s}^{-1}$ for $30 \%$ of the time of the measurements and peaked at up to $75 \mathrm{~cm} \mathrm{~s}^{-1}$. Mienis et al. (2007) reported current speeds exceeding $45 \mathrm{~cm} \mathrm{~s}^{-1}$ down-slope of the carbonate mounds at the SW Rockall Trough margin, located $5 \mathrm{~km}$ distance from our St. 3. We do not have current speeds measured directly above the St. 9 site. However, according to White et al. (2007), the average current speed is less than $5 \mathrm{~cm} \mathrm{~s}^{-1}$ at the base of the slope of the Rockall Bank area.

The biopolymeric C content (BPC - quantity of organic matter available to benthic consumers measured on dry weight of surface sediment) in the studied area varied between $0.51 \mathrm{C} \mathrm{mg} \mathrm{g}^{-1}$ at the open slope stations and $1.54 \mathrm{C} \mathrm{mg} \mathrm{g}^{-1}$ in the CWC area (see Bongiorni et al., 2010 for details of biochemical methods). Protein to carbohydrate ratios, indicating the quality of the organic matter (Pusceddu et al., 2009), varied between 0.22 at the open slope stations and 0.31 in the CWC area.

\subsection{Sampling}

Sediment samples were collected at 8 sites during cruise 64PE249 of R.V. Pelagia (19 June-7 July 2006) within the framework of the HERMES project (Duineveld and shipboard scientific crew, 2006). Samples containing live CWC were collected at four stations at water depths of 567-657 m (Sts. 4-7), and samples without CWC were collected at four stations, characterised by a coarse-grained lag deposit of ice-rafted debris and winnowed sand, along a bathymetric transect across the SE Rockall Bank between 469 and $1958 \mathrm{~m}$ water depth. One of these slope stations (St. 2) was located up-slope of the mound, whereas the other three (Sts. 1, 3, 9) were located further down-slope (Table 1 and Fig. 1). The samples were collected using a NIOZ-boxcorer with a 50-cm diameter cylindrical coring barrel and a top valve preventing washout of the core. After removing the larger pieces of live and dead corals and other large fauna lying loosely on the 
Table 1

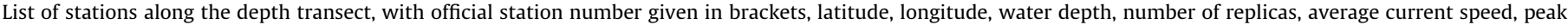
current speed and sediment facies. For current data see text for more detailed explanations and references. na =not available.

\begin{tabular}{|c|c|c|c|c|c|c|c|}
\hline Station & Latitude & Longitude & $\begin{array}{l}\text { Water depth } \\
\text { (m) }\end{array}$ & $\begin{array}{l}\text { Number of } \\
\text { replicates }\end{array}$ & $\begin{array}{l}\text { Average current } \\
\left(\mathrm{cm} \mathrm{s}^{-1}\right)\end{array}$ & $\begin{array}{l}\text { Current peak } \\
\left(\mathrm{cm} \mathrm{s}^{-1}\right)\end{array}$ & Sediment facies \\
\hline St. 2 (BX16A) & $55.65000 \mathrm{~N}$ & $15.79855 \mathrm{~W}$ & 469 & 3 & $\sim 15$ & 75 & Winnowed sand \\
\hline St. 4 (BX8A) & $55.50333 \mathrm{~N}$ & $15.78592 \mathrm{~W}$ & 657 & 3 & 9 & 30 & CWC \\
\hline St. 5 (BX10B) & $55.49988 \mathrm{~N}$ & $15.79893 \mathrm{~W}$ & 591 & 3 & 9 & 30 & CWC \\
\hline St. 6 (BX28A) & $55.49790 \mathrm{~N}$ & $15.81007 \mathrm{~W}$ & 588 & 3 & 9 & 30 & CWC \\
\hline St. 7 (BX36) & $55.49515 \mathrm{~N}$ & $15.80933 \mathrm{~W}$ & 567 & 3 & 9 & 30 & CWC \\
\hline St. 1 (BX12) & $55.45180 \mathrm{~N}$ & $15.76608 \mathrm{~W}$ & 1091 & 2 & 16 & 65 & Coarse grained lag-deposit \\
\hline St. $3(\mathrm{BX} 30 \mathrm{~A})$ & $55.38068 \mathrm{~N}$ & $15.65310 \mathrm{~W}$ & 1488 & 3 & na & 45 & Coarse grained lag-deposit \\
\hline St. 9 (BX79A) & $55.20755 \mathrm{~N}$ & $15.77933 \mathrm{~W}$ & 1958 & 1 & $\sim 5$ & na & na \\
\hline
\end{tabular}

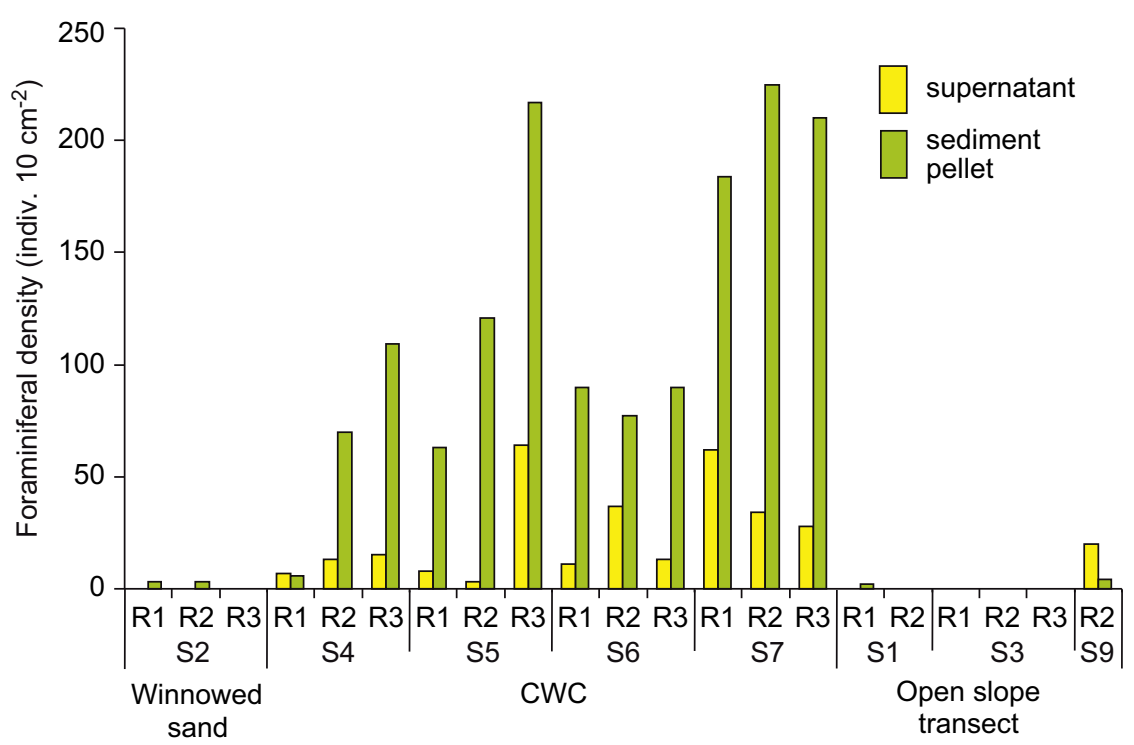

Fig. 3. Number of 'live' benthic foraminifera per $10 \mathrm{~cm}^{2}$ (indiv. $10 \mathrm{~cm}^{-2}$ ) in the supernatant (LUDOX fraction) and sediment pellet.

sediment surface, replicate subcores were taken using a PVC coring tube $(3.6 \mathrm{~cm}$ internal diameter) (Table 1$)$. Subcores were frozen at $-20^{\circ} \mathrm{C}$, which still enabled the identification of all organisms, including the soft-shelled foraminifera (Danovaro, 2010), until analysis in the laboratory.

\subsection{Foraminiferal analyses}

This study is based on the analysis of 'live' (Rose Bengal stained) and dead (unstained) benthic foraminifera from the top $1 \mathrm{~cm}$ of the replicate subcores. After extraction, subcore slices were preserved in a buffered $4 \%$ formalin solution until further processing in the laboratory. In order to compare patterns of foraminiferal and metazoan meiofaunal diversity (Bongiorni et al., 2010) the sediment samples were shared. The samples were washed through screens with a mesh size of $1000 \mu \mathrm{m}$ and $20 \mu \mathrm{m}$. The residue remaining on the latter sieve was resuspended and centrifuged three times with LUDOX HS40 (density $1.31 \mathrm{~g} \mathrm{~cm}^{3}$ ), and stained for $24 \mathrm{~h}$ with Rose Bengal. After the metazoans had been removed (Bongiorni et al. 2010), the two fractions, i.e. the sediment residue (LUDOX retained fraction, hereafter termed the 'sediment pellet') and the floated residue (supernatant), were sieved over a $63-\mu \mathrm{m}$ sieve and sorted separately in water under a stereomicroscope for stained benthic foraminifera. LUDOX extractions $(n=3)$ typically have an efficiency $>98 \%$ for metazoan meiofauna (Danovaro, 2010) but a lower efficiency for foraminifera (Burgess, 2001; Sabbatini et al., 2002), due to the fact that many benthic foraminifera have heavy tests. In
Table 2

Extraction efficiency of LUDOX for different groups of foraminifera.

\begin{tabular}{llll}
\hline Taxon & $N$ & $\begin{array}{l}\text { Mean extraction } \\
\text { efficiency (\%) }\end{array}$ & SD \\
\hline Soft-walled taxa & 13 & 84.9 & 18.2 \\
MAF & 13 & 0.4 & 1.2 \\
Miliolids & 10 & 0 & - \\
Calcareous perforate taxa & 16 & 4.1 & 12.6 \\
\hline
\end{tabular}

$\mathrm{MAF}=$ multilocular agglutinated foraminifera; $\mathrm{SD}=$ standard deviation; $\mathrm{N}=$ number of replicates in which each group of foraminifera was identified.

the present study, this problem was solved by manually picking out the foraminifera remaining in the sediment pellet after extraction in the density gradient. Most of the foraminifera with mineralised test (agglutinant and calcareous) remained in the sediment pellet after centrifugation, whereas the majority of the soft-shelled foraminifera floated in the supernatant (Fig. 3). The efficiency of LUDOX extraction technique was ca. $85 \%$ for the soft-shelled foraminifera, ca. $4 \%$ for the calcareous perforate foraminifera, $0.4 \%$ for multilocular agglutinated foraminifera and $0 \%$ for miliolids (Table 2). Heavier monothalamous foraminifera with predominately agglutinated walls (Lagenammina, Psammosphaeridae and Saccamminidae), were mainly found in the sediment pellet. The counts from the supernatant and sediment pellet were combined and normalised to $10 \mathrm{~cm}^{2}$ for subsequent data interpretation. 
The picked specimens were stored on micropaleontological slides (hard-shelled species) or in glycerol on cavity slides (softshelled species). In the case of calcareous species, only individuals in which most chambers were stained were regarded as having been alive when collected. In the case of multilocular agglutinated and miliolid species, where no stained protoplasm was visible from the exterior, the test was broken in order to establish the presence or absence of stained cytoplasm. The protoplasm of soft-shelled taxa such as allogromiids often contained numerous stercomata and sediment grains and therefore did not stain as clearly as that of calcareous species. However, because the delicate organic or agglutinated wall is likely to decompose rapidly after death, all intact individuals that displayed some degree of staining were recorded as live. Tubular Astrorhizida (mainly Hyperammina and Rhizammina) were usually fragmented. We counted fragments separately and excluded them from all statistical analyses. The dead benthic and planktonic foraminiferal assemblage of one replicate subcore (R2, 0$1 \mathrm{~cm}$ interval) from each station was analysed after all stained foraminifera had been removed. The sample was dried in an oven at $40{ }^{\circ} \mathrm{C}$, and then split with a microsplitter in order to obtain a subsample containing about 250 specimens.

Foraminiferal specimens were identified when possible to the species level in both the 'live' and dead assemblages, based largely upon the taxonomic concepts of Loeblich and Tappan (1994), Gooday and Hughes (2002) and Cornelius and Gooday (2004). Small specimens in which distinctive features were not clearly developed were counted as 'juvenile'. The category 'indeterminate' was used when the genus could not be determined; however, within this category, taxa were distinguished based on test morphology and included in calculations of diversity indices.
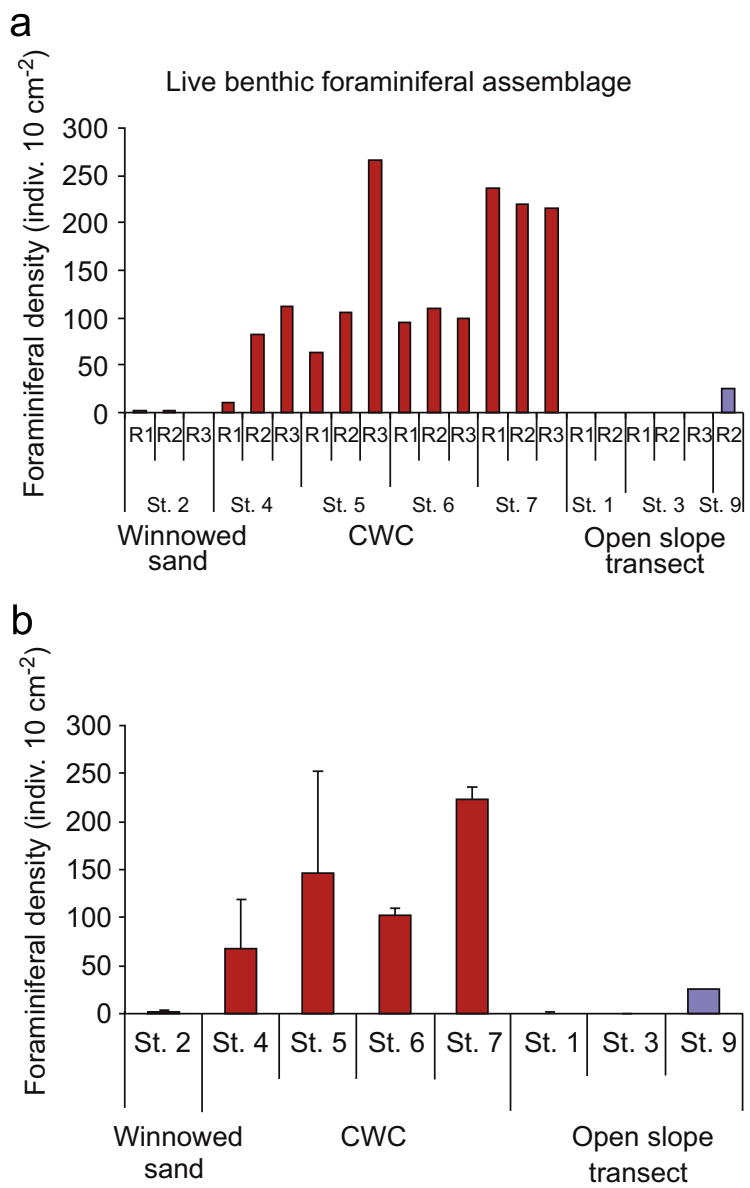

\subsection{Diversity indices and data processing}

The following diversity indices were calculated: (a) Foraminiferal species richness was calculated as the total number of species identified in each replicate subcore; (b) Standardised species richness was calculated as the expected number of species $E\left(S_{x}\right)$ for a theoretical sample of 51 specimens (Hurlbert, 1971); (c) Species diversity $\left(H^{\prime}\right.$, using log-base $e$ ) was measured by the ShannonWiener information function and Fisher $\alpha$ index. All indices reported above were calculated using PAST v. 1.86b (Hammer et al., 2001).

For the calcareous species, we calculated L/D ('live'/dead) ratios from percentages re-calculated after removing all noncalcareous taxa (i.e. all the soft-shelled foraminifera and agglutinated foraminifera).

Canonical correspondence analysis (CCA) was performed using PAST v. 1.86b (Hammer et al., 2001). We selected 7 environmental parameters, water depth, average current speed, protein, carbohydrate, lipid, biopolymeric organic C (BPC), phytopigments (from Bongiorni et al., 2010), and 31 benthic foraminiferal species, each of which representing $>3 \%$ of the total 'live' foraminiferal abundance in at least one sample. Data from Sts. 1-3 were not included due to the low number of living foraminifera.

\section{Results}

\subsection{Abundance, taxonomic composition and diversity of the 'live' assemblage}

CWC sediment samples (Sts. 4-7) yielded an average stained foraminiferal density of $135 \pm 67$ indiv. $10 \mathrm{~cm}^{-2}$ (Fig. 4), of which 
a
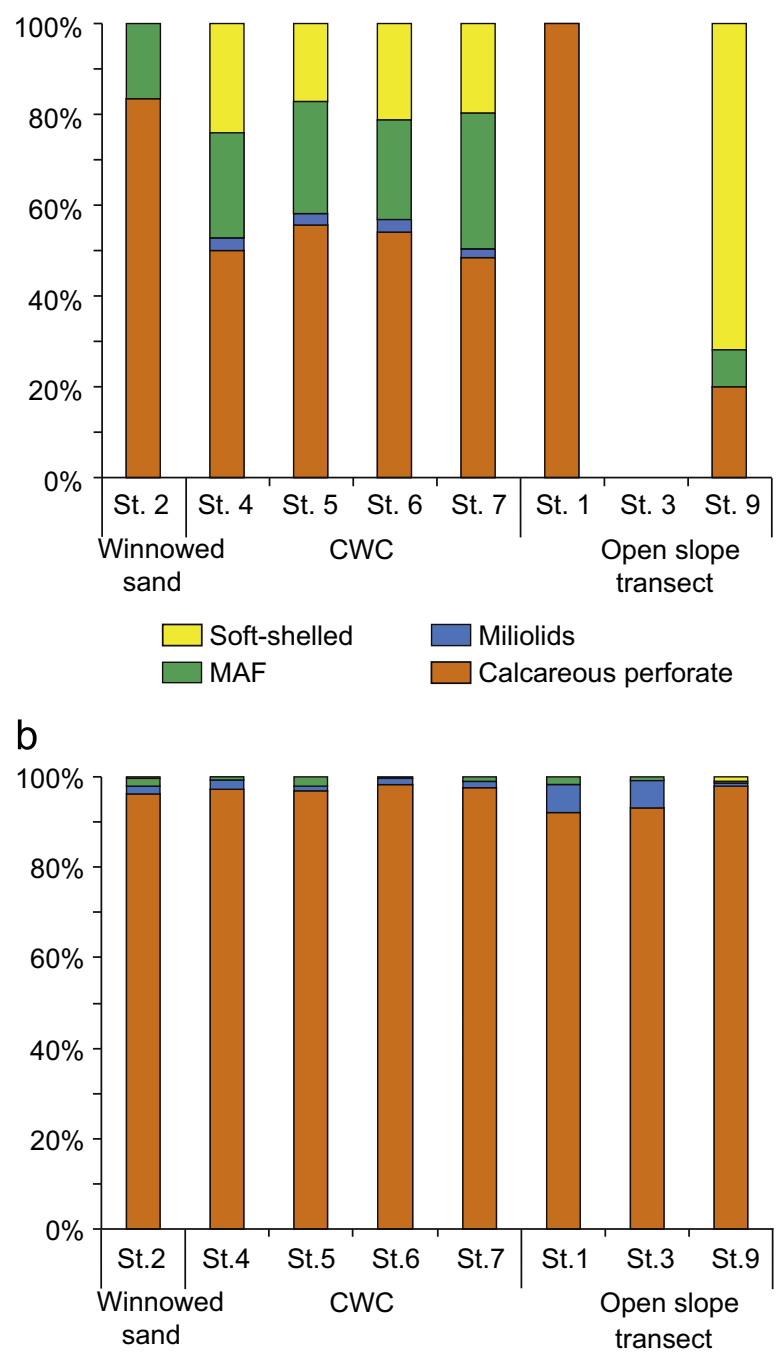

Fig. 5. Proportions of the main groups of foraminifera in (a) the 'live' and (b) the dead foraminiferal assemblages; multilocular agglutinated foraminifera (MAF).
$20 \%$ belonged to soft-shelled taxa, $26 \%$ to multilocular agglutinated taxa, $2 \%$ to miliolids and $52 \%$ to calcareous taxa (Fig. 5). Several tubular fragments of Hyperammina and Rhizammina, and two different species of Gromia (a group related to the foraminifera), were excluded when calculating densities (Fig. 6). Three species, Allogromiid sp. 1, Spirillina vivipara and Eponides pusillus, were most abundant in the CWC area and Adercotryma wrighti, Discoanomalina coronata and Globocassidulina subglobosa appeared among the top 10 most abundant species in three out of the four CWC stations (Table 3). Among soft-shelled taxa, Allogromiid sp. 1, Allogromiid sp. 9, Allogromiid sp. A and Saccamminid sp. 5 were the most abundant (Fig. 7). A significant proportion ( $\sim 10 \%)$ of allogromiids, saccamminids and psammosphaerids could not be separated easily into morphospecies and therefore were considered as indeterminate.

Foraminifera were virtually absent along the bathymetric transect on the open slope (Sts. 1, 3 and St. 9) and at the winnowed sandy site (St. 2). None of the replicates from St. 3, or from St. 1 (R2) and St. 2 (R3), yielded any 'live' foraminifera. The other samples, from St. 2 (R1 and R2), St. 1 (R1) and St. 9 (R2), yielded an average density of $7 \pm 12$ indiv. $10 \mathrm{~cm}^{-2}$, of which $55 \%$ were soft-shelled foraminifera, 9\% multilocular agglutinated foraminifera (Eggerella bradyi) and 36\% were calcareous perforate species (Hoeglundina elegans, Nonionella iridea and C. refulgens) (Fig. 5a). Soft-shelled taxa were found only at St. 9, where Allogromiid sp. 1 was dominant; Allogromiid sp. 9 also occurred here, together with typical deep-sea taxa (Nodellum, Resigella polaris, Saccamminid sp. 5 and 'silver' Saccamminid) (Table 3 and Fig. 7).

A total of 163 benthic foraminiferal species belonging to 71 genera was identified in the sediment samples. Species richness (number of species/station) varied from 0 (St. 3) to a maximum of 89 species at St. 7 (Table 4). CWC stations contained 67-89 species, while only 1-15 species were found at sites along the bathymetric transect (Table 4). The Shannon-Wiener diversity index $\left(H^{\prime}\right)$ had its highest value ( $>3.0$ ) in the CWC area. Values of $E\left(S_{51}\right)$ in the CWC area ranged from 22 (St. 5 R3) to 33 (St. 4 R3).

\subsection{Abundance, taxonomic composition and diversity of the dead assemblage}

The average density of dead foraminifera was higher in the CWC samples than in samples from the bathymetric transect

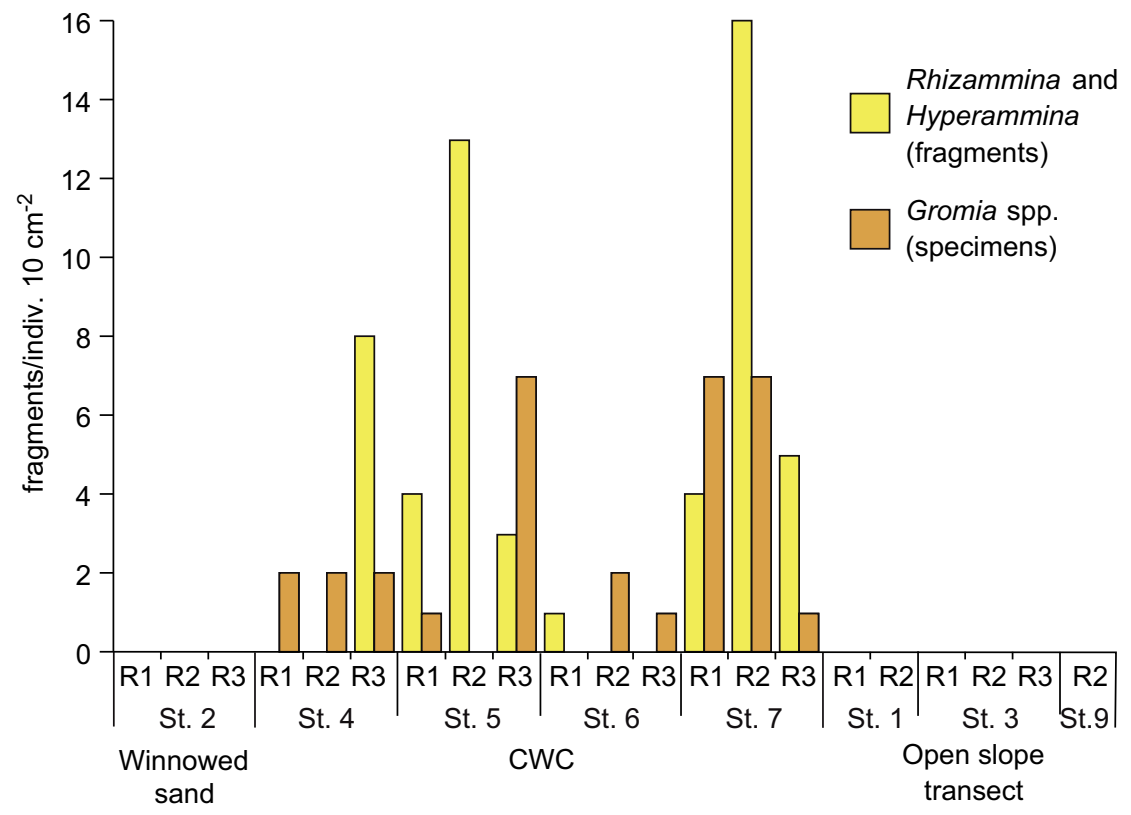

Fig. 6. Abundance of tubular foraminifera (Rhizammina and Hyperammina) (fragments per $10 \mathrm{~cm}^{-2}$ ) and Gromia spp. (indiv. $10 \mathrm{~cm}^{-2}$ ) at the study sites. 
Table 3

Top 10 species in the 'live' and dead assemblages.

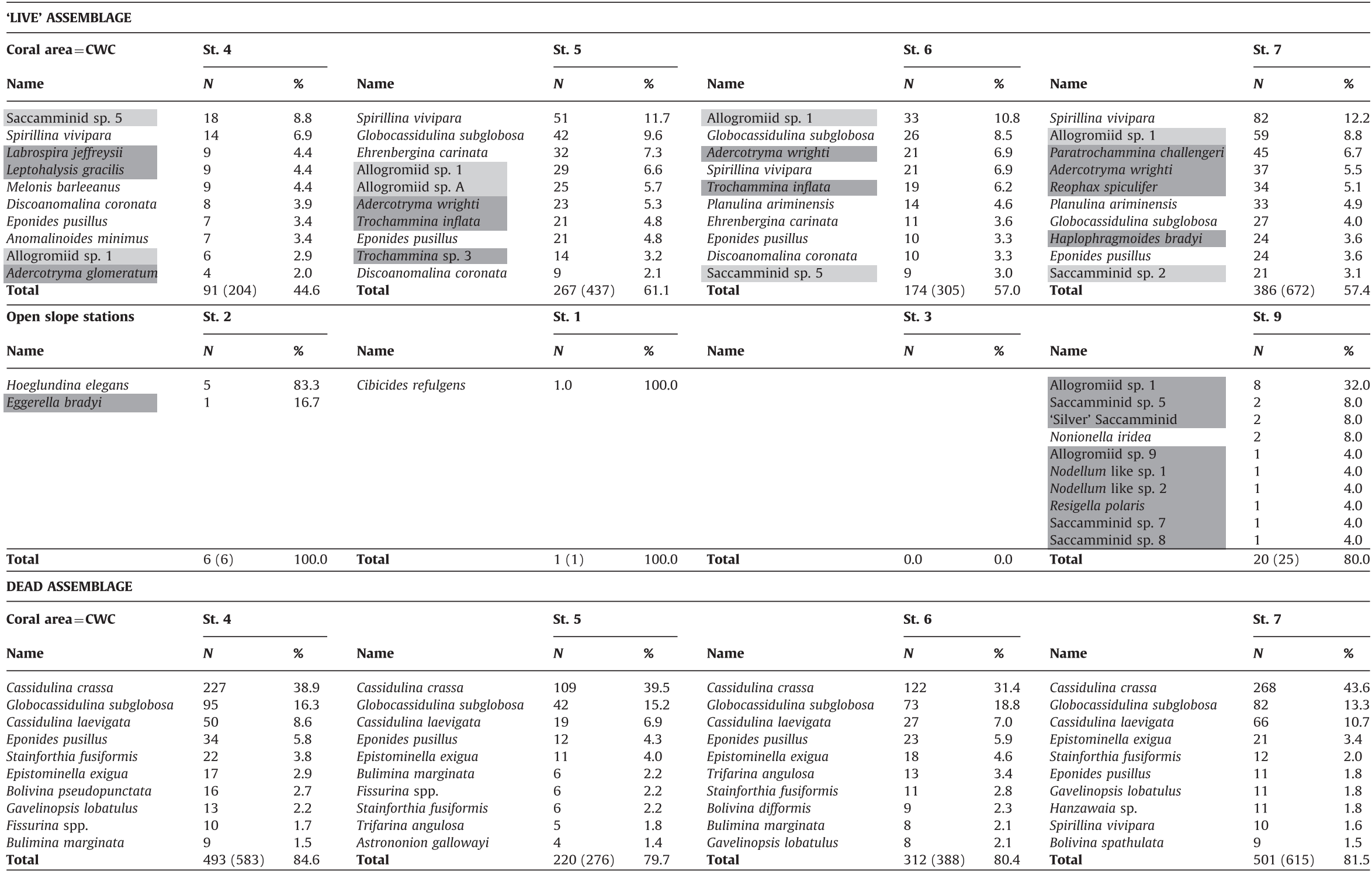




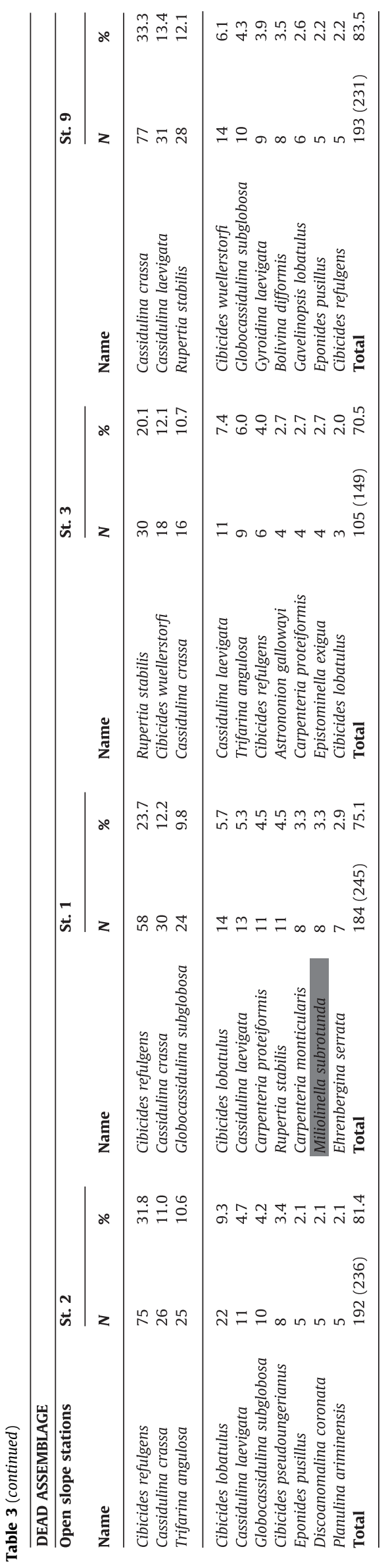

(Fig. 4c). Calcareous species, mainly rotaliids, accounted for $90 \%$ or more of all specimens in the dead assemblages (Fig. 5b) and the other orders were relatively much less abundant in the dead than in the 'live' assemblage. In particular, allogromiids, saccamminids and psammosphaerids, important components of the 'live' fauna, were virtually absent. The dead assemblages from the four CWC sites were very similar (Sts. 4-7; Table 3). At all sites, the three dominant species were Cassidulina crassa, G. subglobosa and Cassidulina laevigata. Another three species, E. pusillus, Epistominella exigua and Stainforthia fusiformis, were among the 10 most abundant dead species in all samples. Gavelinopsis lobatulus and Bulimina marginata also were abundant in three out of the four CWC samples examined.

The dead assemblages in the samples collected along the bathymetric transect (Sts. 1, 3 and St. 9) and at the winnowed sand station (St. 2) were quite different from those collected in the CWC area. Perforate calcareous species characterised by robust, trochospiral tests, such as C. refulgens, Rupertia stabilis, Carpenteria proteiformis, and C. monticularis, were among the most abundant in at least two samples. These species had poorly preserved shells and were probably reworked specimens of glacial age. C. crassa, C. laevigata, C. lobatulus and G. subglobosa were also abundant in dead assemblage.

A total of 97 benthic foraminiferal species belonging to 64 genera was identified in the dead assemblages. Species richness (number of species/station) varied from 33 (St. 9) to a maximum of 47 species at St. 7. Sediments from CWC contained 40-47 species, whilst 33-39 species were found at sites along the bathymetric transect. The Shannon-Wiener diversity index $\left(H^{\prime}\right)$ was fairly constant in all the samples, varying between 2.33 and 3.01. Values of $E\left(S_{51}\right)$ in the CWC area ranged from 15 to 17 , and in the slope samples from 16 to 22 (Table 5).

\section{3. 'Live' vs. dead assemblage}

The dead assemblages in the CWC area yielded substantially fewer species, and had consistently lower values for all diversity indices, compared to the 'live' assemblages (Tables 2 and 5). In contrast, the dead assemblages of the open slope transect had consistently higher values for all the diversity indices compared to the 'live' assemblages. The $\mathrm{L} / \mathrm{D}$ ratios varied from zero for species that present only in the dead assemblages to values $<1$ for species with higher relative abundance in the dead than the 'live' assemblages, and higher values (1-50) for species that were much more abundant in the 'live' assemblages. The $\mathrm{L} / \mathrm{D}$ ratios (Table 6 ) varied widely between species. In summary, in the CWC area C. crassa, C. laevigata, E. exigua and G. subglobosa, had consistently lower percentages in the 'live' than in the dead fauna, whereas A. minimus, E. carinata, M. barleeanus, $P$. ariminensis and $S$. vivipara had consistently higher percentages in the 'live' than in the dead fauna. At the four bathymetric transect stations, all species showed lower percentages in the 'live' than in the dead assemblage, except for Trifarina angulosa.

\subsection{Canonical correspondence analysis}

The output of the CCA performed on the live benthic assemblages, revealed that the linear combination of the tested explanatory variables (i.e. water depth, average current speed, protein, carbohydrate, lipid, BPC and phytopigments) explained $77 \%$ of the variation in the living foraminiferal assemblage composition (Fig. 8 and Table 7). The first axis accounted 55\% of the variation, positive values were mainly influenced by depth and negative values by average current speed, BPC and protein. The four CWC stations had negative values on axis 1, whereas St. 9 had a 


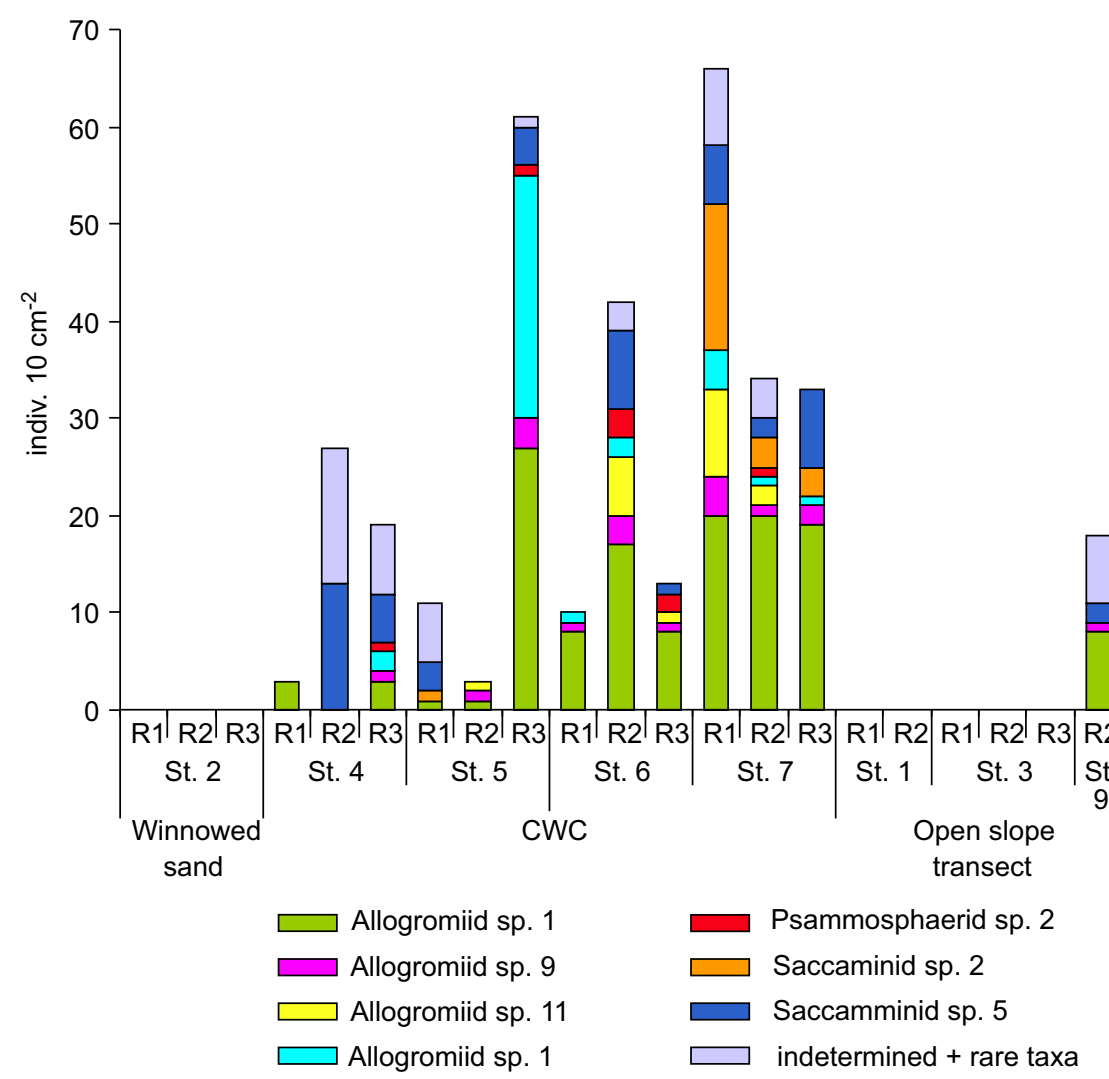

Fig. 7. Abundance (indiv. $10 \mathrm{~cm}^{-2}$ ) of different taxa and indeterminate forms, in the 'live' soft-shelled foraminiferal assemblage.

Table 4

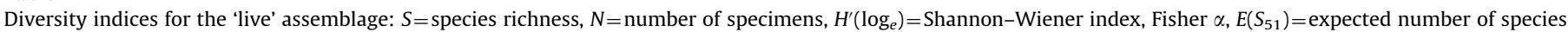
nd $=$ not determined.

\begin{tabular}{|c|c|c|c|c|c|c|c|}
\hline Site & Replica & Sediment facies & $\mathbf{S}$ & $N$ & $H^{\prime}\left(\log _{e}\right)$ & Fisher $\alpha$ & $E\left(S_{51}\right)$ \\
\hline \multirow[t]{3}{*}{ St. 2} & $\mathrm{R} 1$ & Winnowed sand & 1 & 3 & 0.00 & 0.53 & nd \\
\hline & $\mathrm{R} 2$ & & 2 & 3 & 0.64 & 2.62 & nd \\
\hline & R3 & & 0 & 0 & nd & nd & nd \\
\hline \multirow[t]{3}{*}{ St. 4} & $\mathrm{R} 1$ & CWC & 7 & 11 & 1.85 & 8.29 & nd \\
\hline & $\mathrm{R} 2$ & & 29 & 82 & 3.01 & 16.00 & $22.93 \pm 1.73$ \\
\hline & R3 & & 52 & 111 & 3.71 & 38.13 & $32.91 \pm 2.28$ \\
\hline \multirow[t]{3}{*}{ St. 5} & $\mathrm{R} 1$ & CWC & 32 & 64 & 3.19 & 25.47 & $27.82 \pm 1.49$ \\
\hline & $\mathrm{R} 2$ & & 37 & 106 & 3.11 & 20.19 & $24.01 \pm 2.16$ \\
\hline & R3 & & 46 & 267 & 3.15 & 16.02 & $21.80 \pm 2.35$ \\
\hline \multirow[t]{3}{*}{ St. 6} & $\mathrm{R} 1$ & CWC & 33 & 96 & 3.16 & 17.78 & $24.48 \pm 1.91$ \\
\hline & $\mathrm{R} 2$ & & 42 & 110 & 3.30 & 24.82 & $26.89 \pm 2.23$ \\
\hline & R3 & & 33 & 99 & 3.13 & 17.33 & $24.16 \pm 1.93$ \\
\hline \multirow[t]{3}{*}{ St. 7} & $\mathrm{R} 1$ & CWC & 61 & 237 & 3.64 & 26.59 & $28.61 \pm 2.52$ \\
\hline & $\mathrm{R} 2$ & & 53 & 219 & 3.31 & 22.23 & $24.58 \pm 2.51$ \\
\hline & R3 & & 48 & 216 & 3.18 & 19.13 & $23.24 \pm 2.39$ \\
\hline \multirow[t]{2}{*}{ St. 1} & $\mathrm{R} 1$ & Coarse grained lag-deposit & 1 & 1 & 0.00 & 0.00 & nd \\
\hline & $\mathrm{R} 2$ & & 0 & 0 & nd & nd & nd \\
\hline \multirow[t]{3}{*}{ St. 3} & $\mathrm{R} 1$ & Coarse grained lag-deposit & 0 & 0 & nd & nd & nd \\
\hline & $\mathrm{R} 2$ & & 0 & 0 & nd & nd & nd \\
\hline & R3 & & 0 & 0 & nd & nd & nd \\
\hline St. 9 & $\mathrm{R} 2$ & nd & 15 & 25 & 2.39 & 15.83 & nd \\
\hline
\end{tabular}

positive loading on the first axis. The second axis accounted $22 \%$ of the total variation and was mainly influenced by the biochemical composition of the organic matter in the sediment. In particular, positive values indicate higher amount of carbohydrates (St. 4), whereas negative values indicates higher amount of phytopigments (St. 7).

\section{Discussion}

\subsection{Abundance of 'live' foraminifera}

Foraminiferal abundance is closely related to food availability when severe oxygen depletion is not a limiting ecological factor 
Table 5

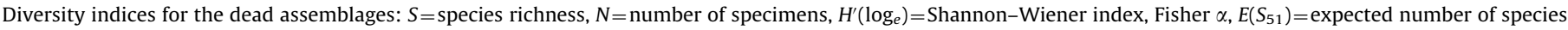
and \% of Neogloboquadrina pachyderma left-coiling in the planktonic foraminiferal assemblage.

\begin{tabular}{|c|c|c|c|c|c|c|c|c|}
\hline Site & Replica & Sediment facies & $\mathbf{S}$ & $N$ & $H^{\prime}\left(\log _{e}\right)$ & Fisher $\alpha$ & $E\left(S_{51}\right)$ & $\begin{array}{l}\% N . \text { pachyderma } \\
\text { left-coiling }\end{array}$ \\
\hline St. 2 & $\mathrm{R} 2$ & Winnowed sand & 34 & 236 & 2.58 & 10.9 & $17.00 \pm 2.12$ & 49 \\
\hline St. 4 & $\mathrm{R} 2$ & CWC & 41 & 583 & 2.37 & 10.1 & $15.13 \pm 2.19$ & 1 \\
\hline St. 5 & $\mathrm{R} 2$ & CWC & 45 & 276 & 2.50 & 15.3 & $17.46 \pm 2.38$ & 2 \\
\hline St. 6 & $\mathrm{R} 2$ & CWC & 40 & 388 & 2.57 & 11.2 & $16.92 \pm 2.20$ & 2 \\
\hline St. 7 & $\mathrm{R} 2$ & CWC & 47 & 615 & 2.33 & 11.8 & $15.51 \pm 2.33$ & 1 \\
\hline St. 1 & $\mathrm{R} 2$ & Coarse grained lag-deposit & 37 & 245 & 2.88 & 12.1 & $19.74 \pm 2.18$ & 50 \\
\hline St. 3 & $\mathrm{R} 2$ & Coarse grained lag-deposit & 39 & 149 & 3.01 & 17.2 & $22.23 \pm 2.28$ & 80 \\
\hline St. 9 & $\mathrm{R} 2$ & nd & 33 & 231 & 2.49 & 10.5 & $16.20 \pm 2.08$ & 14 \\
\hline
\end{tabular}

Table 6

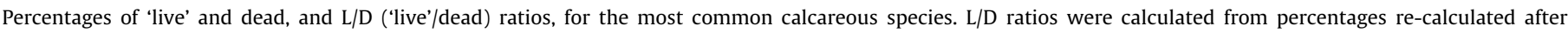
removing all non-calcareous taxa from the 'live' and dead assemblages.

\begin{tabular}{|c|c|c|c|c|c|c|c|c|c|c|c|c|c|c|c|c|c|c|c|c|c|c|c|c|}
\hline & \multicolumn{3}{|c|}{ St. 2} & \multicolumn{3}{|l|}{ St. 4} & \multicolumn{3}{|l|}{ St. 5} & \multicolumn{3}{|l|}{ St. 6} & \multicolumn{3}{|l|}{ St. 7} & \multicolumn{3}{|l|}{ St. 1} & \multicolumn{3}{|c|}{ St. 3} & \multicolumn{3}{|l|}{ St. 9} \\
\hline & $\mathrm{L}$ & $\mathrm{D}$ & $\mathrm{L} / \mathrm{D}$ & $\mathrm{L}$ & $\mathrm{D}$ & $\mathrm{L} / \mathrm{D}$ & $\mathrm{L}$ & $\mathrm{D}$ & $\mathrm{L} / \mathrm{D}$ & $\mathrm{L}$ & $\mathrm{D}$ & $\mathrm{L} / \mathrm{D}$ & $\mathrm{L}$ & $\mathrm{D}$ & $\mathrm{L} / \mathrm{D}$ & $\mathrm{L}$ & $\mathrm{D}$ & $\mathrm{L} / \mathrm{D}$ & $\mathrm{L}$ & $\mathrm{D}$ & $\mathrm{L} / \mathrm{D}$ & $\mathrm{L}$ & $\mathrm{D}$ & $\mathrm{L} / \mathrm{D}$ \\
\hline Anomalinoides minimus & & & & 6.5 & 0.3 & 21.7 & 1.6 & 0.4 & 4.0 & 1.2 & 0.0 & & 2.1 & 0.0 & & & & & & & & & & \\
\hline Cassidulina crassa & 0.0 & 11.3 & 0.0 & 0.0 & 39.2 & 0.0 & 1.2 & 40.4 & 0.0 & 4.0 & 31.5 & 0.1 & 1.2 & 44.0 & 0.0 & 0.0 & 12.4 & 0.0 & 0.0 & 10.8 & 0.0 & 0.0 & 33.8 & 0.0 \\
\hline Cassidulina laevigata & 0.0 & 4.8 & 0.0 & 0.0 & 8.6 & 0.0 & 0.0 & 7.0 & 0.0 & 0.0 & 7.0 & 0.0 & 0.0 & 1.8 & 0.0 & 0.0 & 5.4 & 0.0 & 0.0 & 7.4 & 0.0 & 0.0 & 13.6 & 0.0 \\
\hline Cibicides lobatulus & 0.0 & 9.5 & 0.0 & 1.9 & 0.7 & 2.7 & 0.0 & 0.4 & 0.0 & 0.6 & 0.8 & 0.8 & 2.4 & 0.8 & 3.0 & 0.0 & 5.8 & 0.0 & 0.0 & 2.0 & 0.0 & 0.0 & 0.4 & 0.0 \\
\hline Cibicides refulgens & 0.0 & 32.5 & 0.0 & 0.9 & 0.2 & 4.5 & & & & & & & 0.3 & 0.0 & & 100.0 & 24.1 & 4.1 & 0.0 & 4.1 & 0.0 & 0.0 & 2.2 & 0.0 \\
\hline Ehrenbergina carinata & 0.0 & 0.4 & 0.0 & 3.7 & 0.3 & 12.3 & 12.6 & 0.4 & 31.5 & 6.4 & 0.3 & 21.3 & 3.6 & 0.2 & 18.0 & 0.0 & 2.9 & 0.0 & & & & & & \\
\hline Epistominella vitrea & & & & 0.9 & 2.9 & 0.3 & 1.2 & 4.1 & 0.3 & 0.6 & 4.7 & 0.1 & 1.5 & 3.4 & 0.4 & 0.0 & 1.2 & 0.0 & 0.0 & 2.7 & 0.0 & 0.0 & 2.2 & 0.0 \\
\hline Eponides pusillus & 0.0 & 2.2 & 0.0 & 6.5 & 5.9 & 1.1 & 8.3 & 4.4 & 1.9 & 5.8 & 5.9 & 1.0 & 7.1 & 1.8 & 3.9 & 0.0 & 1.2 & 0.0 & 0.0 & 1.4 & 0.0 & 0.0 & 2.2 & 0.0 \\
\hline Globocassidulina subglobosa & 0.0 & 4.3 & 0.0 & 2.8 & 16.4 & 0.2 & 16.5 & 15.6 & 1.1 & 15.0 & 18.9 & 0.8 & 8.0 & 13.5 & 0.6 & 0.0 & 10.0 & 0.0 & 0.0 & 1.4 & 0.0 & 0.0 & 4.4 & 0.0 \\
\hline Melonis barleeanus & 0.0 & 0.4 & 0.0 & 8.3 & 0.0 & & 0.4 & 0.0 & & 4.0 & 0.0 & & 3.0 & 0.2 & 15.0 & 0.0 & 1.2 & 0.0 & 0.0 & 0.7 & 0.0 & 0.0 & 0.9 & 0.0 \\
\hline Planulina ariminensis & 0.0 & 2.2 & 0.0 & 2.8 & 0.9 & 3.1 & 2.8 & 1.1 & 2.5 & 8.1 & 1.6 & 5.1 & 9.8 & 1.1 & 8.9 & 0.0 & 2.1 & 0.0 & & & & & & \\
\hline Rupertia stabilis & & & & & & & & & & & & & & & & 0.0 & 4.6 & 0.0 & 0.0 & 20.3 & 0.0 & 0.0 & 12.3 & 0.0 \\
\hline Spirillina vivipara & & & & 13.0 & 0.0 & & 20.1 & 0.4 & 50.3 & 12.1 & 0.3 & 40.3 & 24.3 & 1.6 & 15.2 & 0.0 & 0.4 & 0.0 & & & & & & \\
\hline Stainforthia fusiformis & & & & 1.9 & 3.8 & 0.5 & 0.0 & 2.2 & 0.0 & 0.0 & 2.8 & 0.0 & 0.3 & 2.0 & 0.2 & & & & 0.0 & 1.4 & 0.0 & & & \\
\hline Trifarina angulosa & 0.0 & 10.8 & 0.0 & 0.0 & 0.9 & 0.0 & 3.5 & 1.9 & 1.8 & 1.7 & 3.4 & 0.5 & 5.3 & 1.3 & 4.1 & 0.0 & 2.1 & 0.0 & 0.0 & 6.1 & 0.0 & 20.0 & 1.8 & 11.1 \\
\hline
\end{tabular}

(Morigi et al., 2001). Live foraminifera were more abundant in CWC samples where a higher amount of organic matter was present than in the open slope sediments (Fig. 9), where biochemical values were consistently low. CCA revealed that the amount of organic matter explained between-station variability along axis 1 . In particular, CWC stations had high negative values on axis 1 , that corresponded to high amount of organic matter (higher values of all biochemical compounds) (Figs. 8 and 9), whereas St. 9 was characterised by positive values of axis 1 , which were negatively correlated with the quantity of organic matter and positively related to water depth. This is consistent with evidence that the coral framework promotes the sedimentation of fine particles and organic matter and creates a relatively sheltered environment in which trapped organic detritus is available to associated biota (Mienis et al., 2009; De Haas et al., 2009).

Comparisons between our results and previous studies on samples taken at comparable water depth and environmental conditions in North Atlantic are hampered by the use of different size sieves (150 or $250 \mu \mathrm{m}$ compared to $63 \mu \mathrm{m}$ in the present study; see Table 8 for references), the fact that our samples were sorted wet, and the inclusion of the soft-shelled tests that are routinely overlooked in geologically oriented studies. The foraminiferal densities obtained from the CWC area (68-224 indiv. $10 \mathrm{~cm}^{-2}$ ) were slightly lower than those reported from the 63 to $150 \mu \mathrm{m}$ fraction along an open slope transect in the Bay of Biscay (550-2000 $\mathrm{m}, \sim 75-400$ indiv. $10 \mathrm{~cm}^{-2}$; Duchemin et al., 2007) and much lower than the high values reported by Gooday and Hughes (2002) in the nearby Rockall Trough ( $>63 \mu \mathrm{m}, 1913-$
$1980 \mathrm{~m}, 830-2379$ indiv. $10 \mathrm{~cm}^{-2}$ ) (Table 8). Nardelli et al. (2010) found lower foraminiferal density ( $>63 \mu \mathrm{m}, 959-1002 \mathrm{~m}, 40-78$ indiv. $10 \mathrm{~cm}^{-2}$ ) at open slope stations on the Portuguese margin, an area characterised by the same concentration of phytopigments and BPC in the sediments. The very low densities that we obtained from the winnowed sand and open-slope stations are very unusual for bathyal continental margin settings. The open slope stations (Sts. 1-3) are influenced by strong currents (Table 1) and characterised by coarse-grained lag deposits, indicating either a lack of sedimentation or an erosive regime (De Haas et al., 2009). St. 9, the deepest site (1958 m), experienced more oligotrophic conditions, as the labile component of the organic matter rapidly diminishes with water depth, and its deposition can be strongly influenced by lateral advection (Morigi et al., 2001). The flux of organic matter to the deep-sea floor is the main parameter structuring benthic foraminiferal faunas, controlling their density and species composition (Jorissen et al., 2007). Thus, a reduced organic matter flux can sustain only a small standing stock of benthic foraminifera.

It appears, therefore, that foraminiferal densities at the CWC sites are not enhanced compared to normal open slopes of similar water depth, but rather that the open slope sites in the present study area are severely impoverished. The negative effect that strong currents have on benthic foraminiferal assemblages is to some extent reduced by the presence of the CWC that creates different protected niches and hence hotspots of benthic foraminiferal abundance.

The trend in the abundance of sediment-dwelling foraminifera followed that of the metazoan meiofauna (data from Bongiorni 
a

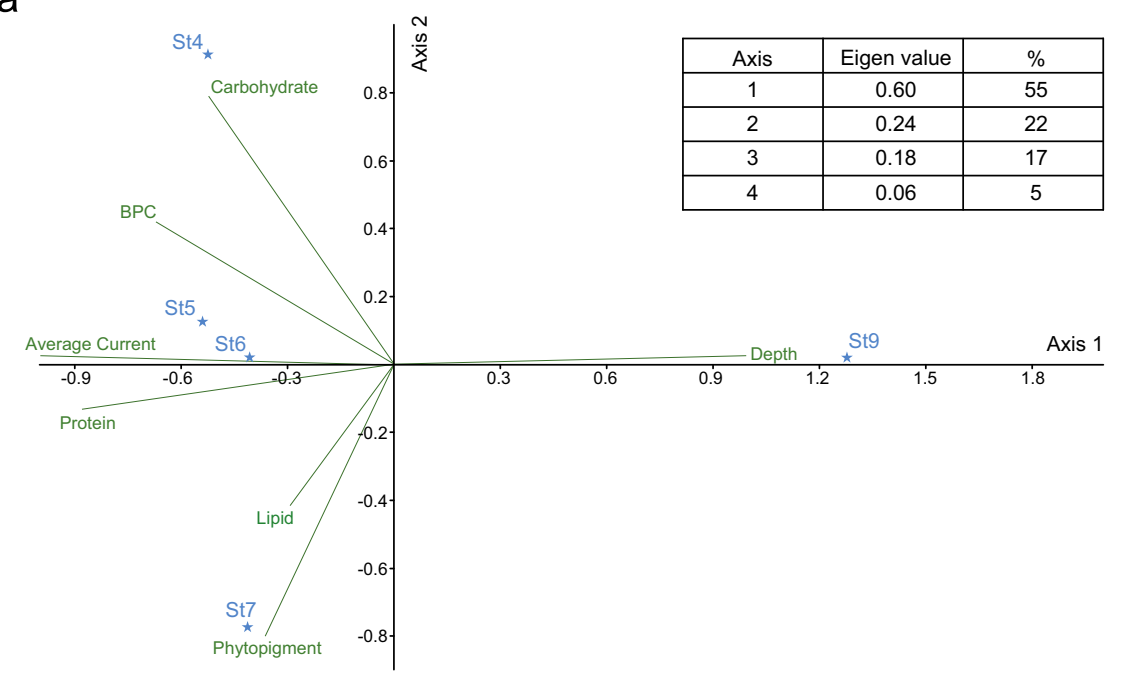

$\mathrm{b}$

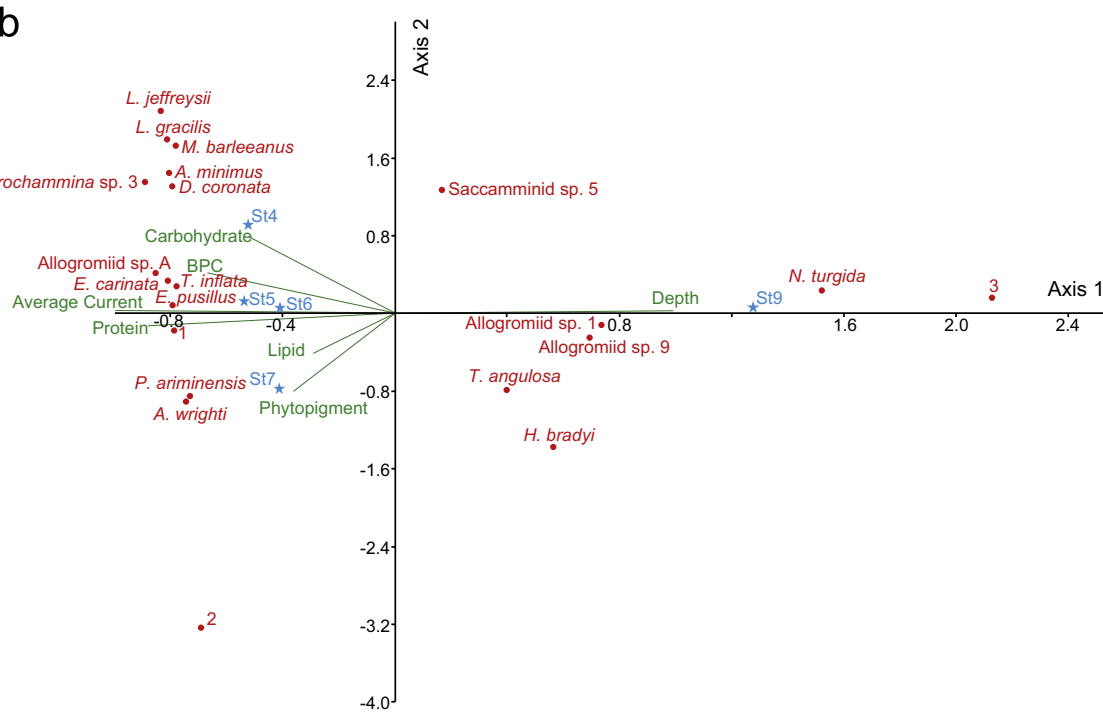

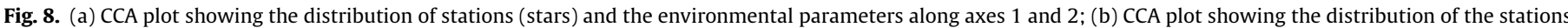

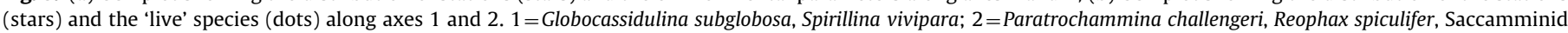
sp. 2; 3 =Haplophragmoides sp., Nodellum-like sp.1, Nodellum-like sp. 2, Nonionella iridea, Resigella polaris, 'silver' Saccamminid, Saccamminid sp. 7; Saccamminid sp. 8.

et al., 2010), although the metazoans outnumbered foraminifera at all sites. Foraminifera constituted $\sim 15 \%$ of the total meiofauna in the CWC area whereas on the open slope the percentage decreased to only $0-0.4 \%$, except at the deepest site (St. 9 ), where the percentage was again 15\% (Fig. 9). This suggests that the metazoan meiofauna coped better with strong currents than the foraminifera. The nematodes, in particular, seem to do well in high energy environments (Bongiorni et al., 2010). Similarly, Garcia et al. (2007) found that in the energetic upper and middle sections of the Nazare canyon on the Portuguese margin were characterised by lower foraminiferal and metazoan densities, but a higher proportion of nematodes.

\subsection{Biodiversity and taxonomic composition of 'live' assemblage}

\subsubsection{Biodiversity}

Biodiversity (number of species, $H^{\prime}$ and Fisher $\alpha$ ) was higher in the CWC area than at the winnowed sand and the open-slope sites and it was higher than that reported in many other studies (see Table 8 for comparison). We believe that this reflects the inclusion of both soft-shelled and hard-shelled species, and the analysis of finer size fraction. On the other hand, we probably underestimated the number of species occupying the CWC habitat, since we analysed only the first centimetre of sediment and not the deeper-dwelling infaunal foraminifera or the epibenthic taxa living on the coral branches. Buhl-Mortensen et al. (2010) suggested that the live tissue of deep-water scleractinian corals prevents attachment of sessile epibiontic foraminiferal species. Only the parasite foraminifera $H$. sarcophaga has direct contact with live coral tissue (Cedhagen, 1994; Buhl-Mortensen and Mortensen, 2004). Several other species can live on dead coral skeletons. Schönfeld et al. (2010) recorded more than 26 species of attached epibenthic foraminifera $(>63 \mu \mathrm{m})$ in the coral area of Galway Mound, Porcupine Seabight. Among them, four species (C. lobatulus, $C$. refulgens, $D$. coronata and $P$. ariminensis) also occurred in our samples. According to Buhl-Mortensen et al. (2010), the highest diversity of associated organisms (metazoan meiofauna, fishes, etc.), is found in the zone with dead coral blocks, where the coral skeletons are exposed and create a more complex three dimensional structure than the rubble zone surrounding the coral reef. Carbonate mounds on the Rockall Bank are covered by a thick layer of dead coral framework and living polyps were usually found on top of the dead framework. This implies that we may have 
Table 7

Results of the canonical correspondence analysis (CCA) considering 31 benthic foraminiferal species representing $>3 \%$ of the total 'live' foraminiferal abundance in at least one sample of the 5 stations and 7 environmental parameters: water depth, average current speed, protein, carbohydrate, lipid, phytopigments, biopolymeric organic carbon (BPC).

\begin{tabular}{|c|c|c|c|c|}
\hline Parameters & Axis 1 & Axis 2 & Axis 3 & Axis 4 \\
\hline Allogromiid sp.1 & 0.73 & -0.14 & -0.18 & -0.41 \\
\hline Allogromiid sp. 9 & 0.69 & -0.25 & -0.59 & -0.93 \\
\hline Allogromiid sp. A & -0.85 & 0.42 & -1.52 & 2.92 \\
\hline Like Nodellum sp. 1 & 2.13 & 0.16 & -0.04 & 0.34 \\
\hline Like Nodellum sp. 2 & 2.13 & 0.16 & -0.04 & 0.34 \\
\hline Resigella polaris & 2.13 & 0.16 & -0.04 & 0.34 \\
\hline Saccamminid sp. 2 & -0.69 & -3.24 & 2.33 & 0.91 \\
\hline Saccamminid sp. 5 & 0.17 & 1.26 & 1.09 & -0.23 \\
\hline Saccamminid sp. 7 & 2.13 & 0.16 & -0.04 & 0.34 \\
\hline Saccamminid sp. 8 & 2.13 & 0.16 & -0.04 & 0.34 \\
\hline Silver Saccamminid & 2.13 & 0.16 & -0.04 & 0.34 \\
\hline Adercotryma wrighti & -0.75 & -0.91 & -0.81 & -1.13 \\
\hline Haplophragmoides bradyi & 0.56 & -1.36 & 0.80 & -0.29 \\
\hline Haplophragmoides sp. & 2.13 & 0.16 & -0.04 & 0.34 \\
\hline Labrospira jeffreysii & -0.84 & 2.08 & 2.38 & 1.20 \\
\hline Leptohalysis gracilis & -0.82 & 1.79 & 1.76 & -0.06 \\
\hline Paratrochammina challengeri & -0.69 & -3.24 & 2.33 & 0.91 \\
\hline Reophax spiculifer & -0.69 & -3.24 & 2.33 & 0.91 \\
\hline Trochammina inflata & -0.78 & 0.27 & -1.58 & -1.32 \\
\hline Trochammina sp. 3 & -0.89 & 1.35 & -1.29 & 4.15 \\
\hline Eponides pusillus & -0.79 & 0.08 & -0.01 & 0.59 \\
\hline Anomalinoides minimus & -0.81 & 1.46 & 1.43 & -0.10 \\
\hline Discoanomalina coronata & -0.80 & 1.32 & 0.54 & -1.01 \\
\hline Ehrenbergina carinata & -0.81 & 0.34 & -1.10 & 0.68 \\
\hline Globocassidulina subglobosa & -0.78 & -0.14 & -1.42 & -0.41 \\
\hline Melonis barleeanus & -0.78 & 1.72 & 1.90 & -1.92 \\
\hline Nonionella iridea & 2.13 & 0.16 & -0.04 & 0.34 \\
\hline Nonionella turgida & 1.52 & 0.23 & -0.63 & 1.36 \\
\hline Planulina ariminensis & -0.73 & -0.85 & -0.02 & -1.71 \\
\hline Spirillina vivipara & -0.79 & -0.15 & 0.13 & 0.65 \\
\hline Trifarina angulosa & 0.39 & -0.80 & -0.11 & 0.74 \\
\hline St. 4 & -0.53 & 0.91 & 0.68 & 0.01 \\
\hline St. 5 & -0.54 & 0.13 & -0.54 & 0.32 \\
\hline St. 6 & -0.41 & 0.02 & -0.35 & -0.44 \\
\hline St. 7 & -0.41 & -0.78 & 0.42 & 0.05 \\
\hline St. 9 & 1.28 & 0.03 & -0.01 & 0.02 \\
\hline Water depth & 0.99 & 0.02 & -0.03 & 0.06 \\
\hline Average current speed & -1.00 & 0.03 & -0.05 & 0.06 \\
\hline Protein & -0.88 & -0.13 & 0.31 & 0.31 \\
\hline Carbohydrate & -0.52 & 0.79 & 0.15 & 0.41 \\
\hline Lipid & -0.29 & -0.42 & 0.61 & 0.52 \\
\hline Phytopigment & -0.36 & -0.80 & 0.09 & 0.35 \\
\hline $\mathrm{BPC}$ & -0.67 & 0.42 & 0.41 & 0.57 \\
\hline
\end{tabular}

missed a substantial number of epifaunal foraminifera and consequently underestimated the biodiversity of the CWC habitat. In contrast, the stations along the slope (Sts. 1-3) had a very low number of species, much lower than other open-slope stations (Table 8). Unfortunately, the very low number of living foraminifera found in the open slope stations does not allow us to include Sts. 1-3 in the CCA. Nevertheless, the highest current speeds (average and maximum values) were recorded at these three stations (Table 1). The current velocity at $50 \mathrm{~cm}$ above the seafloor varied between 3 and $30 \mathrm{~cm} / \mathrm{s}$ with peaks of $65 \mathrm{~cm} / \mathrm{s}$ (Table 1 ). The absence of arborescent foraminifera at the slope stations (Fig. 6) also suggests that these sites are impacted by strong currents. These delicate forms thrive in relatively stable environments characterised by lower current velocities (Koho et al., 2007) and may be damaged by enhanced current flow (Altenbach, 1988). These findings are consistent with the results of other studies (Mackensen et al., 1990, 1993; Schönfeld, 2002), which indicated that physical parameters, especially currents, can strongly affect the benthic foraminiferal assemblages, creating oligotypic associations dominated by few resistant species (i.e. C. lobatulus, C. refulgens and T. angulosa).

\subsubsection{The soft-shelled component (Fig. 10)}

Soft-shelled taxa contributed $20 \%$ of the 'live' foraminiferal assemblage (average density 135 indiv. $10 \mathrm{~cm}^{-2}$ ) in the CWC stations and $72 \%$ at St. 9 on the open slope (Fig. 5a). Several of the most common species have never been found before, either in the Northeast Atlantic or in CWC habitats. Most are undescribed, but several belong to known genera (Nodellum, Resigella and Tinogullmia). Some resemble species reported from other locations, although the conspecificity of these morphologically simple forms is difficult to establish without molecular data. The most abundant species, Allogromiid sp. 1 (Fig. 10-1), is similar to Allogromiid sp. 1 from the Porcupine Seabight (Gooday, 1986, Fig. 3b therein) and the central Equatorial and North Pacific (Gooday et al., 2004, Fig. 5e therein). Pancotti (2011) discovered a similar morphotype in the deep Western Mediterranean Sea. Allogromiid sp. 9 (Fig. 10-2) closely resembles a species with the same numerical designation from much shallower depths in the North Adriatic (Sabbatini et al., 2010, Pl. 1, Fig. 5 therein). A similar organic-walled allogromiid is also present at abyssal depths in the Mediterranean basin (Pancotti, 2011). Allogromiid sp. A (Fig. 10-3), an organic-shelled form with two apertures, is common in our CWC samples. This form ranges from spindle-shaped to cylindrical and contains numerous stercomata (waste pellets). Saccamminid sp. 5 (Fig. 10-7), which has one terminal aperture, represents a morphotype that is common in the deep North Atlantic, Indian and Pacific Oceans (=Saccamminid sp. 5 in Gooday 1994, Fig. 3F; Gooday et al., 2004, Fig. 6D-G). It is also very similar to a form reported from the upper bathyal ( $\sim 900 \mathrm{~m}$ water depth) western Mediterranean (Heinz, 1999) and the abyssal Alboran Sea (Western Mediterranean) (Pancotti, 2011). A 'silver saccamminid' (Fig. 10-8), a morphotype reported at deep-water sites in the Northeast Atlantic and North and Western Equatorial Pacific Oceans (Saccamminid sp. 2 in Gooday et al., 2004, Fig. 6A-C) as well as the Mediterranean (Pancotti, 2011), occurs at Sts. 7 and 9. The sparse 'live' assemblage at St. 9 is dominated by soft-shelled taxa. Some forms with brownish, organicwalled tests (Nodellum spp. and R. polaris, Figs. 5-5 and 10-6) found exclusively at St. 9, are polythalamous. Pancotti (2011) reported similar morphotypes from the abyssal Mediterranean and the Atlantic off the Straits of Gibraltar. These small forms are common in deep-sea sediments world-wide and probably a ubiquitous component of deep-sea faunas (Gooday et al., 2004).

\subsubsection{The 'live' hard-shelled component (Fig. 11)}

More than $60 \%$ of the foraminifera in our samples belong to hardshelled taxa (Fig. 5a). Epifaunal species (D. coronata, P. ariminensis and S. vivipara), shallow infaunal species that are either often (E. pusillus) or sometimes (G. subglobosa) associated with phytodetritus (Gooday and Lambshead, 1989; Gooday, 1993; Gooday and Hughes, 2002) and taxa typical of high energy environment ( $T$. angulosa and E. carinata) (Mackensen et al., 1990; Schönfeld, 2002), are the most abundant species in our samples (Table 3 and Fig. 12). Schönfeld et al. (2010) reported that living epifaunal specimens of $D$. coronata and $P$. ariminensis occurred in surface sediment samples collected from Galway Mound. D. coronata was also suggested by Margreth et al. (2009) as an useful indicator to identify living CWC facies together with C. lobatulus (reported as Lobatula lobatula). S. vivipara, one of the most abundant 'live' species in our CWC samples, occurs on the Galway Mounds in very low numbers, likely due to the different studied size fraction ( $>250 \mu \mathrm{m}$ in Schönfeld et al., 2010).

The CCA revealed that the quality of organic matter influenced the distribution of the benthic foraminifera. Axis 1 is indicative of the bioavailable organic matter quantity, whereas axis 2 reflects the nutritional quality of the organic matter. The labile carbon content increased towards the negative values of axis 2; a higher content of carbohydrates, generally considered to be refractory compounds (Pusceddu et al., 2009), are suggested by the positive score of 
a

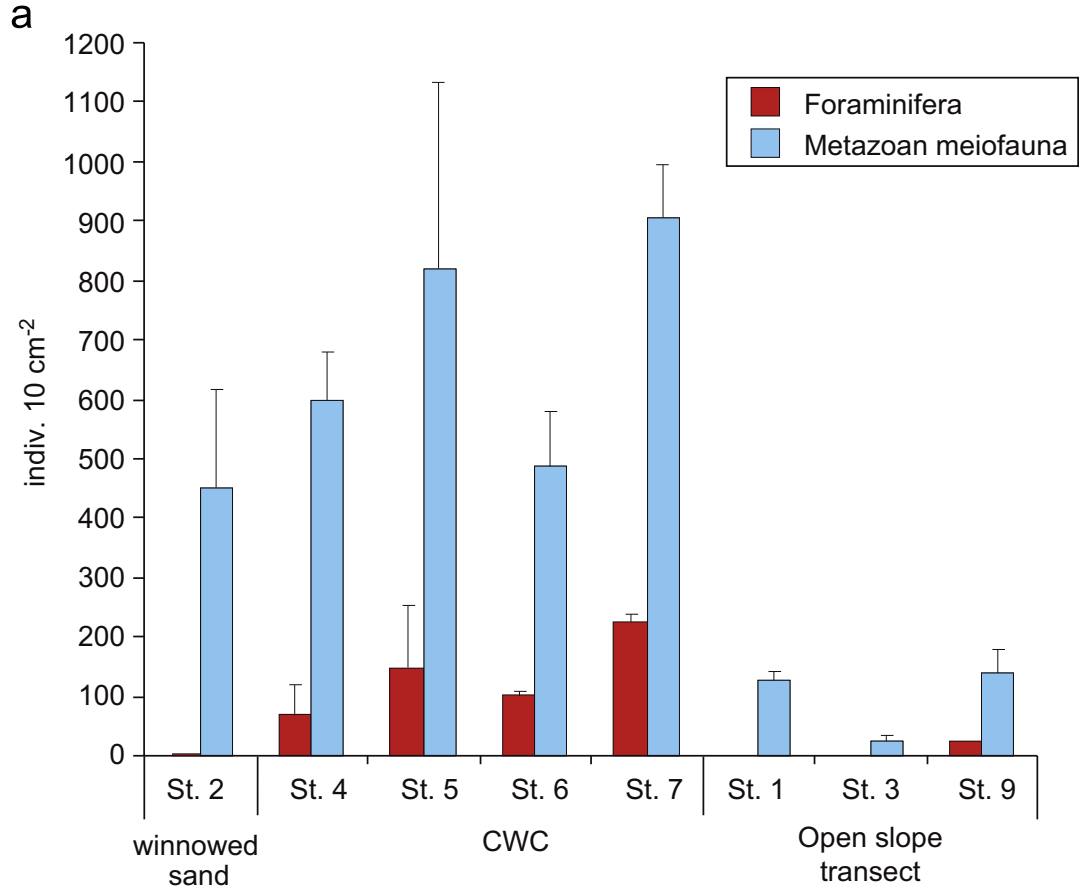

b

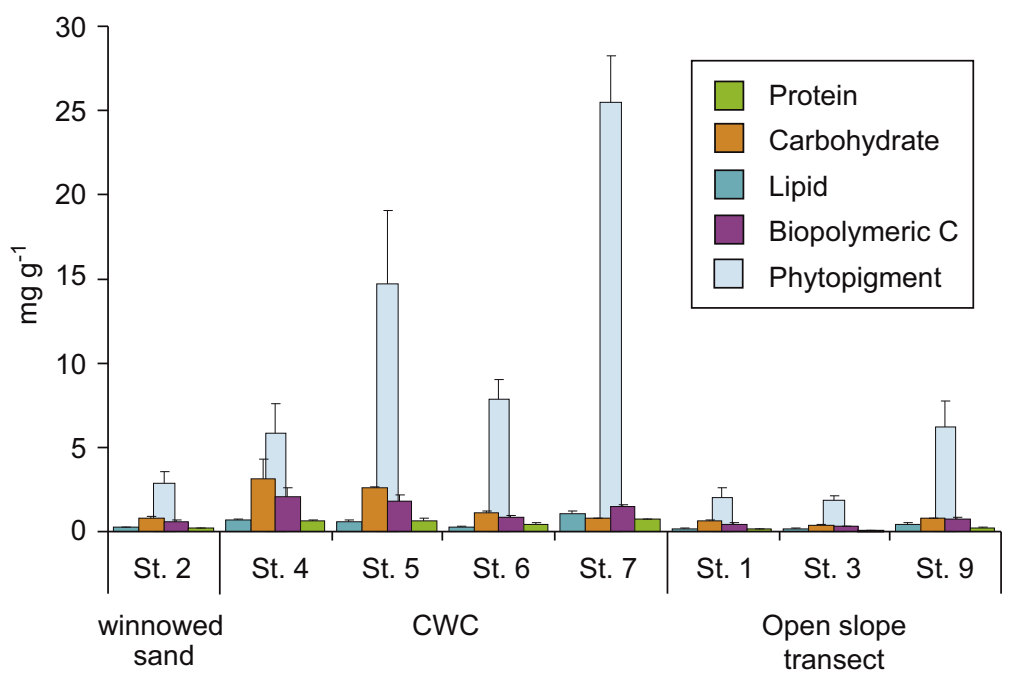

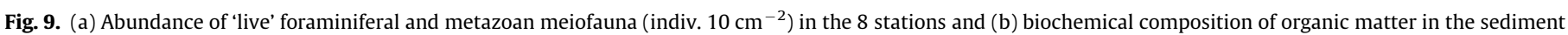
(data from Bongiorni et al., 2010) in the 8 stations. Bars indicate standard deviations.

Melonis barleeanus, a species that appears to be adapted to somewhat degraded organic matter (Caralp, 1989). Decreasing values along axis 2 reflect more labile organic matter (a higher content of protein and phytopigments), as indicated also by the increasing proportion of E. pusillus and G. subglobosa (Gooday and Hughes, 2002; Suhr et al., 2003). E. pusillus, known as a phytodetritus species, is common in this part of the Atlantic Ocean, where it colonises and feeds on aggregates of phytodetritus (Gooday, 1993; Gooday and Hughes, 2002). The ecological requirements of $P$. challengeri, $R$. spiculifer and Saccamminid sp. 2, which had the highest negative scores on axis 2, are unknown, but we speculate that the abundance of these species may be strongly influenced by the presence of a seasonal phytodetritus input.

Although apparently thriving in the CWC habitat, the hardshelled species associated with CWC (D. coronata, E. carinata, E. pusillus, G. subglobosa, P. ariminensis, S. vivipara and T. angulosa) are also known from other habitats, and therefore do not appear to be endemic to the CWC sites.

\subsection{Live/dead ratios}

Differences in 'live' and dead assemblages reflect a combination of biological and taphonomic processes. In particular, differences in test production rates, bioturbation by mega and macro-fauna, dissolution of calcareous tests, disintegration of organic tests and agglutinated tests with organic cement, and transport of smallsized tests (Mackensen et al., 1990, 1993; de Stigter et al., 1999; Jorissen and Wittling, 1999; Murray, 2006) can enhance the abundance in the dead assemblage of the more resistant and high productivity species. For example, most of the agglutinated and soft-shelled taxa are absent from the thanatocoenoses. This illustrates the progressive post-mortem destruction of the test due to degradation of the organic cement (e.g., Mackensen et al., 1990, 1993; de Stigter et al., 1999). The dead assemblages from the CWC and the adjacent slope were very different. $C$. crassa and C. laevigata were very abundant in the dead faunas, but absent in 
Table 8

Comparison of abundance and diversity of foraminiferal microfauna from the Rockall Bank and other open slope and high energy sites.

\begin{tabular}{|c|c|c|c|c|c|c|c|c|c|c|}
\hline Area & $\begin{array}{l}\text { Water } \\
\text { depth (m) }\end{array}$ & Method & $\begin{array}{l}\text { Sieve } \\
(\mu \mathrm{m})\end{array}$ & $\begin{array}{l}\text { Sample } \\
\text { depth }(\mathrm{cm})\end{array}$ & $\begin{array}{l}S \\
(\min -\mathbf{m a x})\end{array}$ & $\begin{array}{l}N\left(\text { ind. } 10 \mathbf{c m}^{-2}\right) \\
(\min -\max )\end{array}$ & $H^{\prime}\left(\log _{e}\right)$ & Fisher $\alpha$ & $\begin{array}{l}\text { Notes on the } \\
\text { study area }\end{array}$ & Ref. \\
\hline Bay of Biscay & $550-2000$ & $\mathrm{RB}$ & $63-150$ & $0-1$ & $39-57$ & $\sim 75-400$ & na & na & Open slope & $\begin{array}{l}\text { Duchemin et al. } \\
\text { (2007) }\end{array}$ \\
\hline Celtic margin & 515-1939 & $\mathrm{RB}$ & $>150$ & $0-10$ & $19-49$ & $9-231$ & $1.88-3.34$ & na & Canyon area & Duros et al. (2011) \\
\hline $\begin{array}{l}\text { Rockall } \\
\text { Trough }\end{array}$ & 1913-1980 & $\mathrm{RB}$ & $>63$ & $0-1$ & $158-176$ & $830-2379$ & na & $33-38.5$ & Bathyal area & $\begin{array}{l}\text { Gooday and Hughes } \\
\text { (2002) }\end{array}$ \\
\hline $\begin{array}{l}\text { Portuguese } \\
\text { margin }\end{array}$ & $344-927$ & $\mathrm{RB}$ & $>150$ & $0-5$ & $30-54$ & $18-32$ & na & na & Canyon terrace & Koho et al. (2007) \\
\hline $\begin{array}{l}\text { Portuguese } \\
\text { margin }\end{array}$ & 959-1002 & $\mathrm{RB}$ & $>63$ & $0-1$ & $40-42$ & $40-78$ & na & na & Open slope & $\begin{array}{l}\text { Nardelli et al. } \\
(2010)\end{array}$ \\
\hline Gulf of Cadiz & 496 & $\mathrm{RB}$ & $250-2000$ & $\begin{array}{l}\text { Uppermost } \\
\mathrm{cm}\end{array}$ & na & $2-41$ & na & na & High energy & Schönfeld (2002) \\
\hline $\begin{array}{l}\text { Galway } \\
\text { Mound }\end{array}$ & $810-982$ & $\mathrm{RB}$ & $>250$ & $\begin{array}{l}\text { Uppermost } \\
\mathrm{cm}\end{array}$ & $4-33$ & na & na & $4.9-15.7$ & CWC & $\begin{array}{l}\text { Schönfeld et al. } \\
\text { (2010) }\end{array}$ \\
\hline Rockall bank & $567-657$ & $\mathrm{RB}$ & $63-1000$ & $0-1$ & $29-61$ & $68-224$ & $1.85-3.71$ & $16-38.1$ & CWC & This study \\
\hline Rockall bank & 469-1958 & RB & $63-1000$ & $0-1$ & $0-15$ & $0-25$ & $0-2.39$ & $0.53-15.8$ & High energy & This study \\
\hline
\end{tabular}

$\mathrm{RB}=$ Rose Bengal; $S=$ species richness, $N=$ number of specimens, $H^{\prime}\left(\log _{e}\right)=$ Shannon-Wiener index, na $=$ not available. $(\mathrm{min}-\mathrm{max})=$ minimum and maximum values.
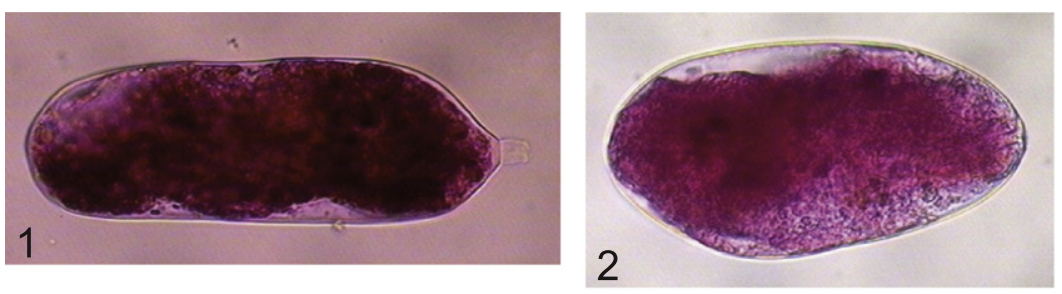

\section{3}
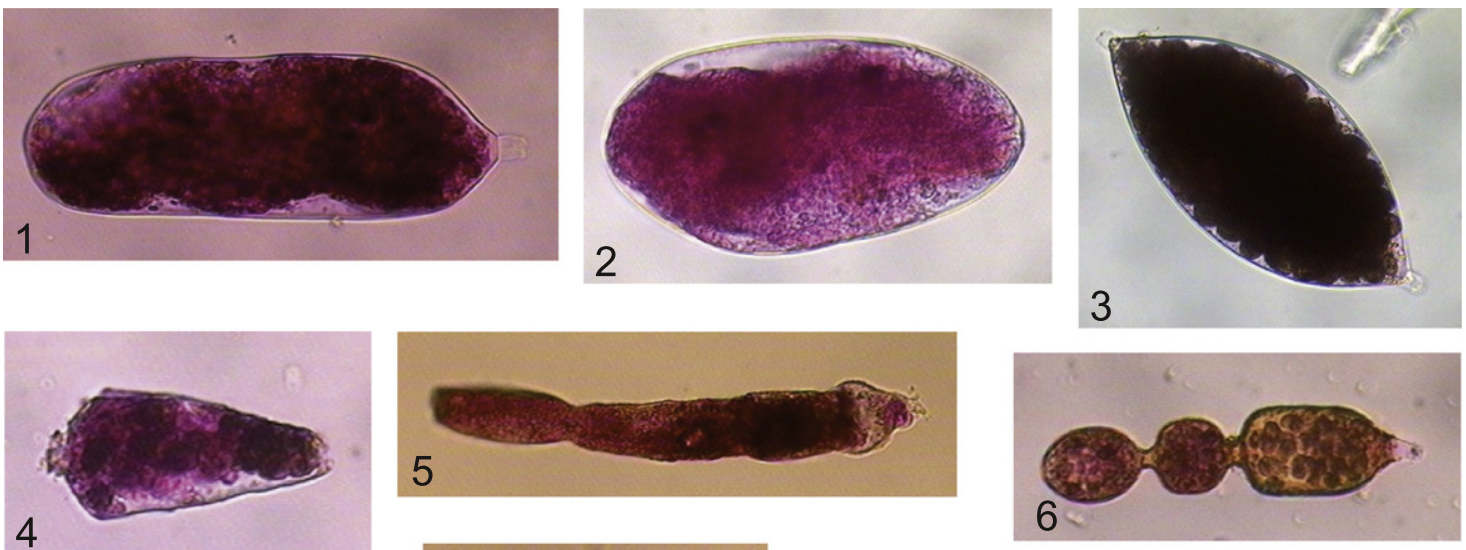

4
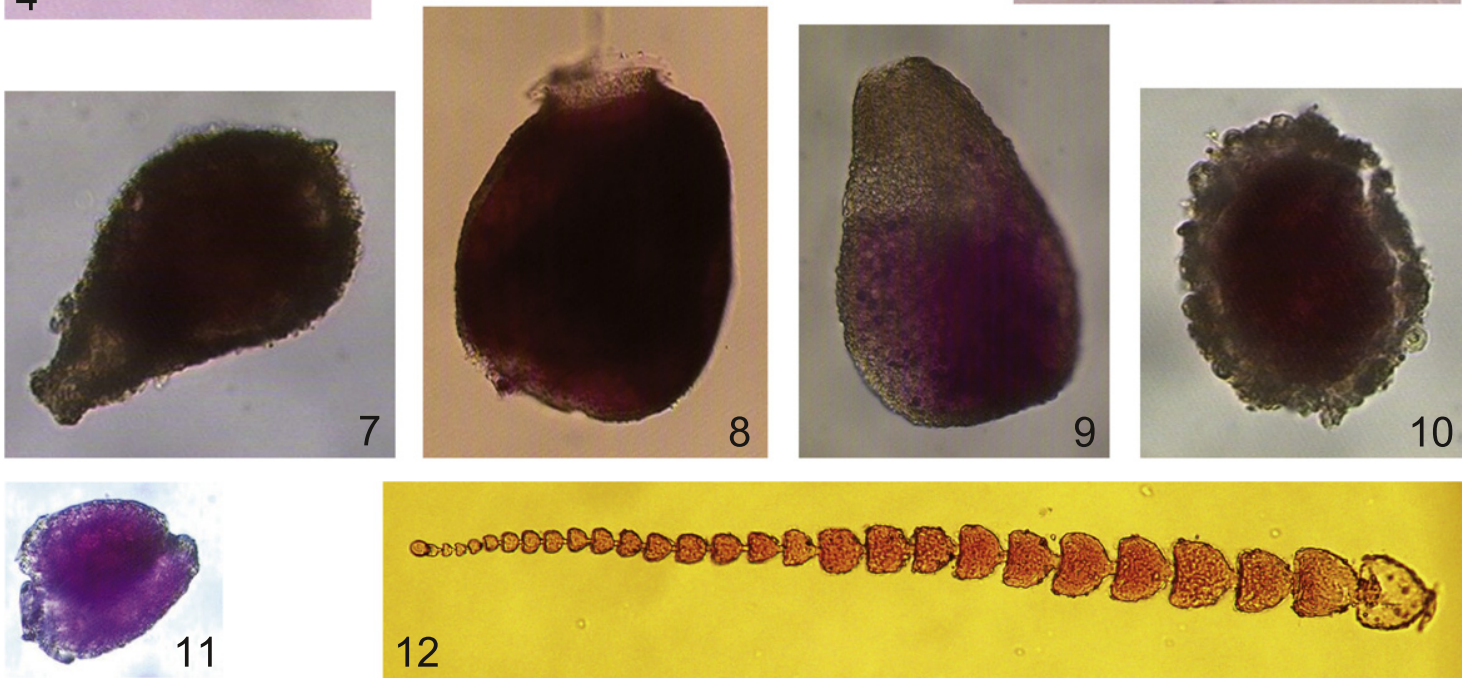

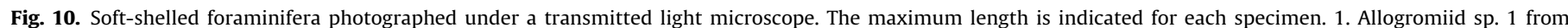

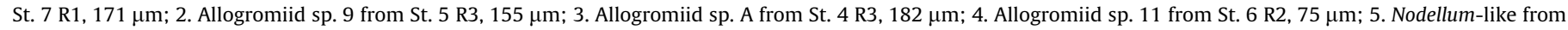

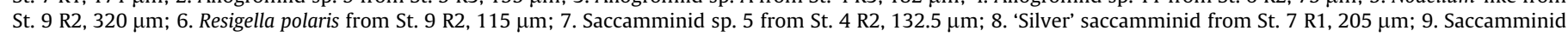

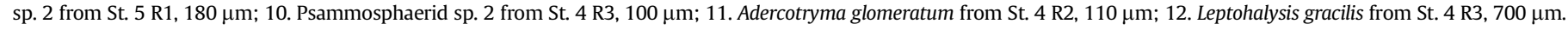

the living assemblages. This reflects opportunistic behaviour leading to rapid test production in these species, which have also been observed to dominate living faunas in other high productivity open slope area (Morigi et al., 2001). As already observed by
Gooday and Hughes (2002) for other cassidulinids, one possible explanation is that the test production in these species occurs later in the summer, perhaps as part of a successional sequence following phytodetritus deposition in spring. E. pusillus and 


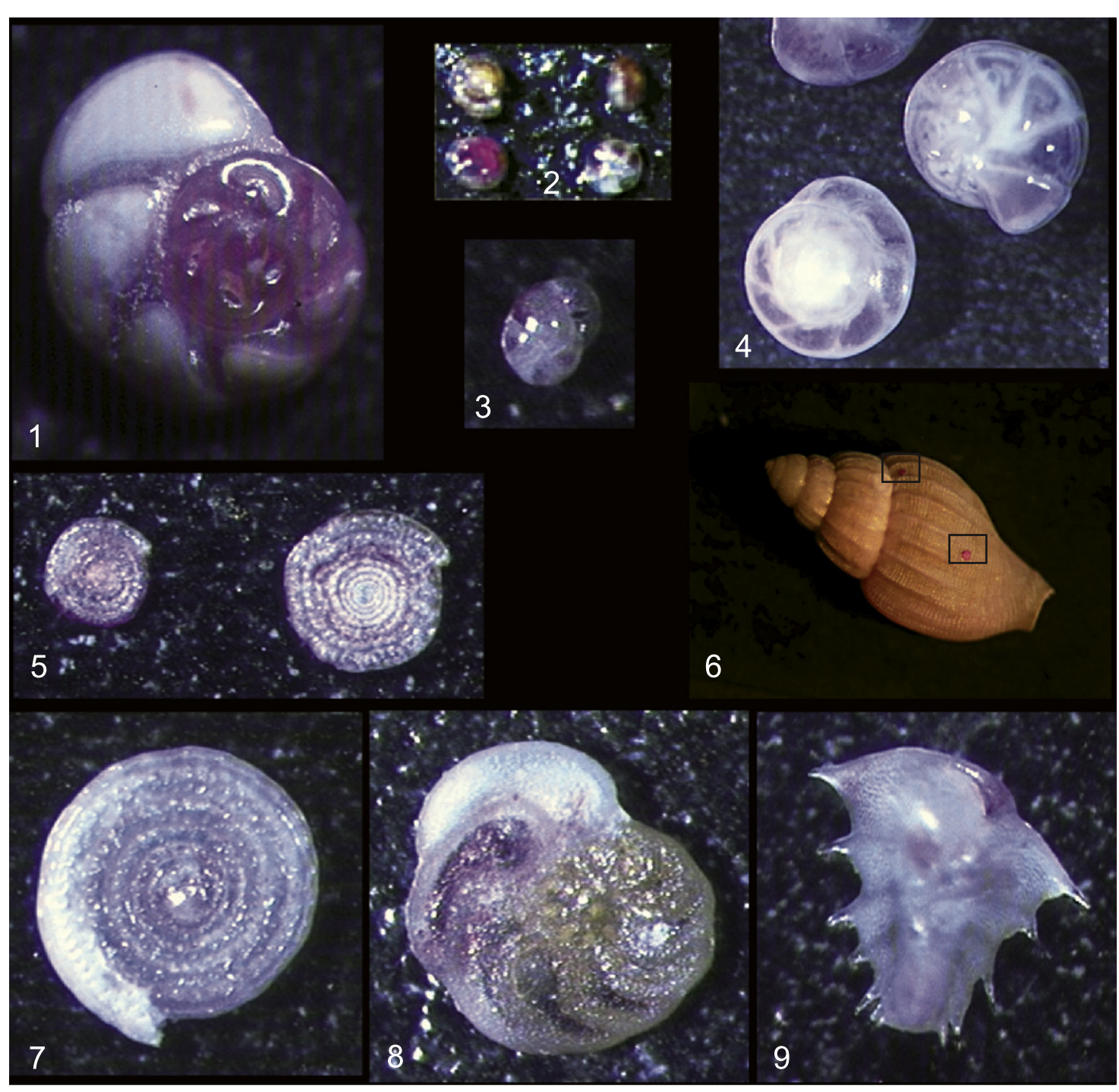

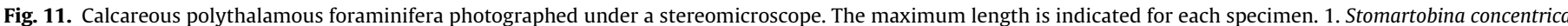

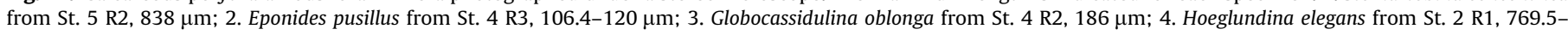

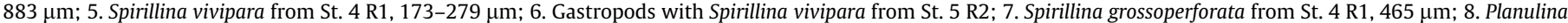
ariminensis from St. 4 R3, 2 mm; 9. Ehrenbergina carinata from St. 4 R3, $505 \mu \mathrm{m}$.

E. exigua, which are considered to be proxies for pulsed inputs of organic matter to the sea floor (phytodetritus species) (Gooday, 1993), showed low L/D ratios, suggesting that the bulk of test production is likely concentrated at another time of the year, but that these species maintained their relatively high abundance in the 'live' assemblage, despite considerable fluctuation in absolute numbers. In addition, the high abundance of these species in the dead assemblages indicated that the phytodetrital signal is recorded in the dead fauna. The same high $\mathrm{L} / \mathrm{D}$ value is shown by $G$. subglobosa. This species has been found living in phytodetrital lumps, but not nearly as often as typical phytodetritus species, such as E. pusillus and E. exigua (Gooday and Lambshead 1989; Gooday, 1988, 1993).

The dead assemblages from our samples were different from the dead assemblage reported in previous CWC studies (Margreth et al., 2009; Schönfeld et al., 2010). In particular Margreth et al. (2009) found that uvigerinids and cassidulinids displayed the highest abundance in off-mound surface sediment. Uvigerinids are absent in our samples, whereas cassidulinids ( $C$. crassa and $C$. laevigata), together with $G$. subglobosa, had higher abundances on-mound in the CWC area. In the case of $C$. refulgens, our results diverge from those of Schönfeld et al. (2010), who found high densities of live specimens in the sand belt around the CWC mounds and a lower proportion in the dead assemblage. We had exactly the opposite result; specimens of $C$. refulgens were virtually absent in the 'live' assemblage and abundant in the dead assemblages (especially in Sts. 1 and 2). The presence of this suspension feeder in high-energy environments on the open slope and at winnowed stations is consistent with the strong near-bottom currents measured in these areas. We found low percentages of $D$. coronata at the CWC stations, as well as at the two stations around the mound (Sts. 1 and 2), whereas Margreth et al. (2009) and Schönfeld et al. (2010) indicated this to be the most frequent species in the on-mound assemblage. Although not a dominant species, $D$. coronata could be a useful proxy for the CWC habitat if found in association with other epifaunal species ( $P$. ariminensis and $S$. vivipara), species associated with high amounts of labile organic matter (E. pusillus and G. subglobosa), and high energy species (e.g. T. angulosa).

\subsection{Possible glacial relics?}

Large ( $>250 \mu \mathrm{m}$ ), typically epibiontic taxa with robust tests (Rupertia spp., Carpenteria spp. and C. refulgens) were present in significant numbers in the dead assemblage at the open slope 


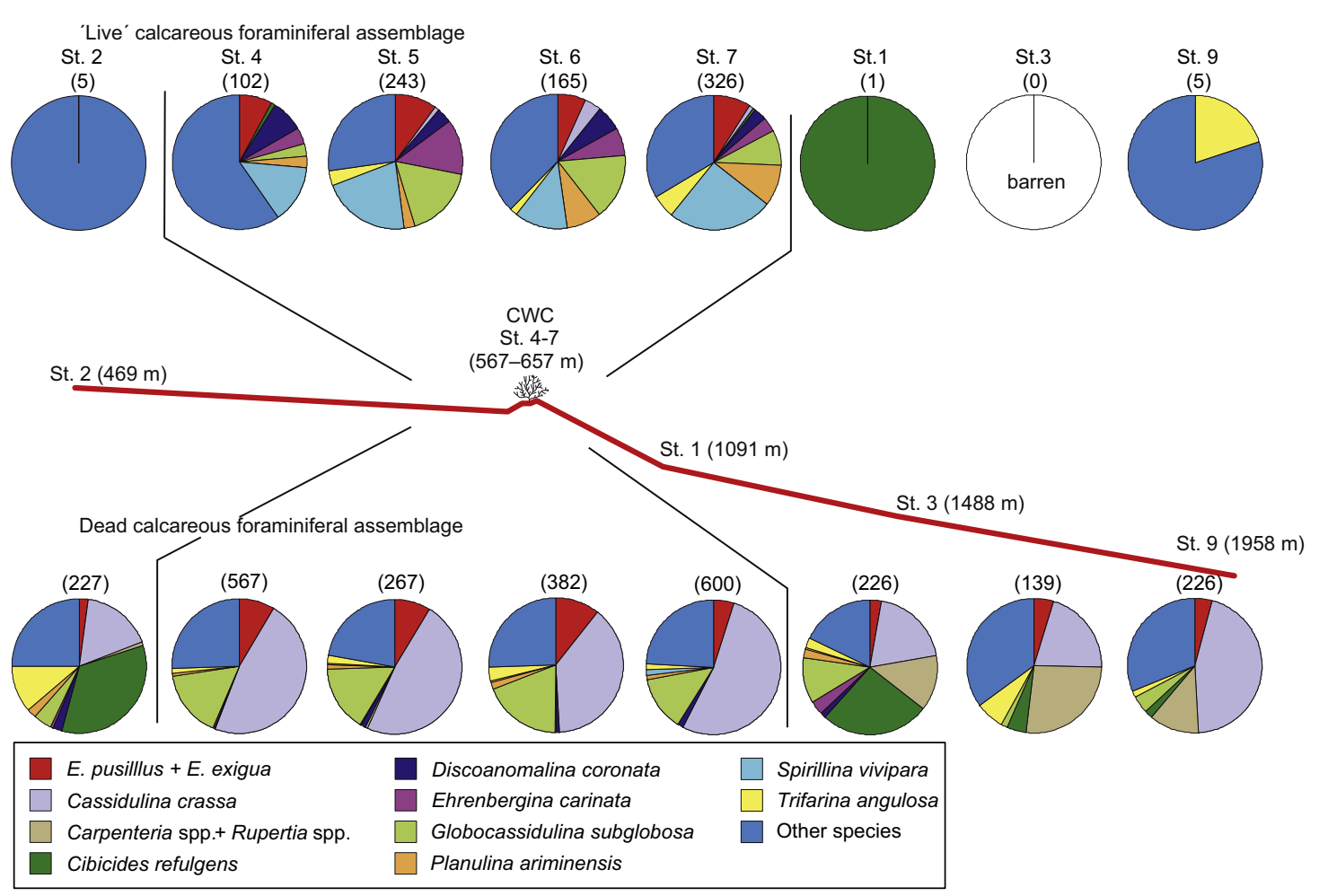

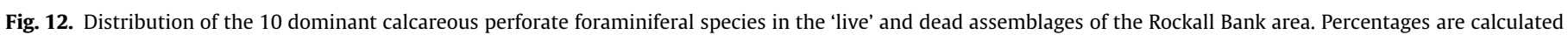
based only on the calcareous perforate foraminiferal assemblage. The number in bracket indicates the calcareous specimens counted in each station.

stations (Sts. 1, 3 and to a lesser extent St. 9) but rare or absent at the CWC sites (Fig. 12). The winnowed lag deposit constituting the surface sediment layer at the open slope sites is mainly composed of ice-rafted sediment of glacial age, and planktonic foraminifera from these sites include a considerable percentage of left-coiled $N$. pachyderma (Table 5), which also indicates a glacial origin. It seems likely that the robust epibenthic species, which have poorly preserved tests, represent reworked glacial fauna. This interpretation is strengthened by the fact that no stained specimens of these 3 taxa occurred in the open slope sites. An alternative interpretation is that Rupertia spp., Carpenteria spp. and C. refulgens live attached to stones and other firm substrata, and therefore were missed in the present study, where only the $>63 \mu \mathrm{m}$ fraction of the first centimetre of sediment was analysed.

\section{Conclusions}

This study of foraminiferal biodiversity on CWC and open slope sites on the Rockall Bank (NE Atlantic) leads to the following conclusions:

- Sediments at the upper bathyal (567-657 m) CWC sites are characterised by significantly higher foraminiferal abundance and species richness than samples from coarse-grained lag deposits and winnowed sands on the adjacent slope (469-1958 m). Some replicate samples from the open slope sites were even barren of living specimens.

- High-velocity bottom currents at the open slope sites apparently prevent the deposition of fine-grained sediment and organic material, creating a hostile environment that epifaunal and shallow infaunal foraminifera are unable to colonise. In contrast, on carbonate mounds, where CWC framework provides a sheltered and heterogeneous habitat, foraminiferal assemblages are characterised by high biodiversity and abundance.

- Foraminifera are less abundant than metazoan meiofauna at both the CWC and open slope sites. However, in both the groups, higher abundance and diversity is associated with the presence of CWC.

- No foraminiferal species were endemic to the Rockall Bank. The CWC area is characterised by a combination of epifaunal (D. coronata, $P$. ariminensis and $S$. vivipara), shallow infaunal (E. pusillus, A. minimus and G. subglobosa) and high energy (E. carinata and $T$. angulosa) species that can be used as indicators of CWC habitat in paleoenvironmental reconstructions.

\section{Acknowledgements}

This work was supported by the HERMES project (Hotspot Ecosystem Research on the Margins of European Seas, contract GOCE-CT-2005-511234, funded by the European Commission's Sixth Framework Programme) and HERMIONE project (Hotspot Ecosystem Research and Man's Impact on European Seas, contract 226354, funded by the European Commission's Seventh Framework Programme. A.J.G. was also supported by the Oceans 2025 project of the UK Natural Environment Research Council. Shiptime for cruise 64PE249 was provided by Royal NIOZ. The authors would like to thank the captain and crew for assistance with the work at sea and they are grateful to Jette Halskov (GEUS) for her help with the figures.

\section{Appendix A. Supplementary material}

Supplementary data associated with this article can be found in the online version at doi:10.1016/j.dsr.2011.10.004. 


\section{References}

Altenbach, A.V., 1988. Deep-sea benthic foraminifera and flux rate of organic carbon. Rev. Paléobiol. 2, 719-720.

Auster, P.J., 2005. Are deep-water corals important habitats for fishes? in: Freiwald, A., Roberts, J.M. (Eds.), Deep-water Corals and Ecosystems, Springer-Verlag, Berlin, Heidelberg, pp. 747-760.

Bongiorni, L., Mea, M., Gambi, C., Pusceddu, A., Taviani, M., Danovaro, R., 2010. Deepwater scleractianian corals promote higher biodiversity in deep-sea meiofaunal assemblages along continental margins. Biol. Conserv. 143, 1687-1700.

Buhl-Mortensen, L., Mortensen, P.B., 2004. Symbiosis in deep-water corals. Symbiosis 37, 33-61.

Buhl-Mortensen, L., Mortensen, P.B., 2005. Distribution and diversity of species associated with deep-sea gorgonian corals off Atlantic Canada. in: Freiwald, A. Roberts, J.M. (Eds.), Cold-water Corals and Ecosystems, Springer-Verlag, Berlin, pp. 849-879.

Buhl-Mortensen, L., Vanreusel, A., Gooday, A.J., Levin, L.A., Priede, I.G., BuhlMortensen, P., Gheerardyn, H., King, N.J., Raes, M., 2010. Biological structures as a source of habitat heterogeneity and biodiversity on the deep ocean margin. Mar. Ecol. 31, 21-50.

Burgess, R., 2001. An improved protocol for separating meiofauna from sediments using colloidal silica sols. Mar. Ecol. Prog. Ser. 214, 161-165.

Caralp, M.H., 1989. Size and morphology of the benthic foraminifer Melonis barleeanum; relationships with marine organic matter. J. Foraminiferal Res. $19,235-245$.

Cedhagen, T., 1994. Taxonomy and biology of Hyrrokkin sarcophaga gen. et sp. n., a parasitic foraminiferan (Rosalinidae). Sarsia 79, 65-82.

Cornelius, N., Gooday, A.J., 2004. 'Live' (stained) deep-sea benthic foraminiferans in the western Weddell Sea: trends in abundance diversity and taxonomic composition along a depth transect. Deep-Sea Res. Part II 51, 1571-1602.

Danovaro, R., 2010. Methods for the Study of Deep-Sea Sediments. Their Functioning and Biodiversity. CRC Press, Boca Raton.

De Haas, H., Mienis, F., Frank, N., Richter, T.O., Steinacher, R., de Stigter, H.C., van der Land, C., van Weering, T.C.E., 2009. Morphology and sedimentology of (clustered) cold water coral mounds at the south Rockall Trough margins NE Atlantic Ocean. Facies 55, 1-26.

de Stigter, H.C., van der Zwaan, G.J., Langone, L., 1999. Differential rates of benthic foraminiferal test production in surface and subsurface sediment habitats in the southern Adriatic Sea. Palaeogeogr. Palaeoclimatol. Palaeoecol. 149, 67-88.

Dorschel, B., Hebbeln, D., Foubert, A., White, M., Wheeler, A.J., 2010. Hydrodynamics and cold-water coral facies distribution related to recent sedimentary processes at Galway Mound west of Ireland. Mar. Geol. 244, 184-195.

Duchemin, G., Fontanier, C., Jorissen, F.J., Barras, C., Griveaud, C., 2007. Living small-sized $(63-150 \mu \mathrm{m})$ foraminifera from mid-shelf to mid-slope environments in the Bay of Biscay. J. Foraminifer. Res. 37, 12-32.

Duineveld, G.C.A., shipboard scientific crew, 2006. Biodiversity ecosystem functioning and food web complexity of cold water coral reefs in the NE Atlantic (Rockall Bank). Cruise 64PE249 Galway-Oban 19 June-7 July 2006 with RV Pelagia.

Duineveld, G.C.A., Lavaleye, M.S.S., Bergman, M.J.N., de Stigter, H.C., Mienis, F., 2007. Trophic structure of a cold-water coral mound community (Rockall Bank NE Atlantic) in relation to the near-bottom particle supply and current regime. Bull. Mar. Sci. 81, 449-467.

Duros, P., Fontanier, C., Metzger, E., Pusceddu, A., Cesbron, F., de Stigter, H.C., Bianchelli, S., Danovaro, R., Jorissen, F.J., 2011. Live (stained) benthic foraminifera in the Whittard Canyon, Celtic margin (NE Atlantic). Deep-Sea Res. Part I $58,128-146$.

Freiwald, A., Fosså, J.H., Grehan, A., Koslow, T., Roberts, J.M., 2004. Cold-water Coral Reefs. UNEP-WCMC, Cambridge.

Freiwald, A., Roberts, J., 2005. Cold-Water Corals and Ecosystem. Springer-Verlag, Berlin, Heidelberg.

Freiwald, A., Schönfeld, J., 1996. Substrate pitting and boring pattern of Hyrrokkin sarcophaga Cedhagen, 1994 (Foraminifera) in a modern deep-water coral reef mound. Mar. Micropaleontol. 28, 199-207.

Garcia, R., Koho, K.A., de Stigter, H.C., Epping, E., Koning, E., Thomsen, L., 2007. Distribution of meiobenthos in the Nazaré Canyon and adjacent slope (western Iberian Margin): is it related to sedimentary composition? Mar. Ecol. Prog. Ser. 340, 207-220.

Gooday, A.J., 1986. Soft-shelled foraminifera in meiofaunal samples from the bathyal northeast Atlantic. Sarsia 71, 275-287.

Gooday, A.J., 1988. A response by benthic foraminifera to the deposition of phytodetritus in the deep sea. Nature 332, 70.

Gooday, A.J., 1993. Deep-sea benthic foraminiferal species which exploit phytodetritus: characteristic features and controls on distribution. Mar. Micropaleontol. 22, 187-205.

Gooday, A.J., 1994. The biology of deep-sea foraminifera: a review of some advances and their applications in paleoceanography. Palaios 9, 14-31.

Gooday, A.J., Hori, S., Todo, Y., Okamoto, T., Kitazato, H., Sabbatini, A., 2004. Softwalled monothalamous foraminifera in the Pacific Ocean: aspects of biodiversity and biogeography. Deep-Sea Res. Pt. I 51, 33-53.

Gooday, A.J., Hughes, J.A., 2002. Foraminifera associated with phytodetritus deposits at a bathyal site in the northern Rockall Trough (NE Atlantic): seasonal contrasts and a comparison of stained and dead assemblages. Mar. Micropaleontol. 46, 83-110.
Gooday, A.J., Lambshead, P.J.D., 1989. The influence of seasonally deposited phytodetritus on benthic foraminiferal populations in the bathyal northeast Atlantic: the species response. Mar. Ecol. Prog. Ser. 58, 53-67.

Hammer, Ø., Harper, D.A.T., Ryan, P.D., 2001. PAST: paleontological statistics software package for education and data analysis. Palaeontologia Electronica 4 PE4.1.4A.

Hawkes, A., Scott, D.B., 2005. Attached benthic Foraminifera as indicators of past and present distribution of the coral Primnoa resedaeformis on the Scotian Margin. in: Freiwald, A., Roberts, J.M. (Eds.), Cold-water Corals and Ecosystems, Springer-Verlag, Berlin, Heidelberg, pp. 881-894.

Heinz, P., 1999. Response of deep-sea benthic foraminifera to simulated phytodetritus pulses under laboratory conditions. Tübinger Mikropaläontolgische Mitteilungen 20.

Hurlbert, S.H., 1971. The non-concept of species diversity: a critique and alternative parameters. Ecology 52, 577-586.

Jensen, A., Frederiksen, R., 1992. The fauna associated with bank-forming deepwater coral Lophelia pertusa (Scleractinaria) on the Faroe shelf. Sarsia 77, 53-69.

Jorissen, F.J., Wittling, I., 1999. Ecological evidence from live/dead comparisons of benthic foraminiferal faunas of Cape Blanc (Northwest Africa). Palaeogeogr. Palaeoclimatol. Palaeoecol. 149, 151-170.

Jorissen, F.J., Fontanier, Thomas, E., 2007. Paleoceanographical proxies based on deep-sea benthic foraminiferal assemblage characteristics. in: Hillaire-Marcel, C., de Vernal, A. (Eds.), Proxies in Late Cenozoic Paleoceanography. Part 2: Biological Tracers and Biomarkers, Elsevier, Amsterdam, pp. 263-326.

Koho, K.A., Kouwenhoven, T.J., de Stigter, H.C., van der Zwaan, G.J., 2007. Benthic foraminifera in the Nazaré canyon Portuguese continental margin: sedimentary environment and disturbance. Mar. Micropaleontol. 66, 27-51.

Loeblich, A.R., Tappan, H., 1994. Foraminifera on the Sahul shelf and Timor Sea. Cushman Foundation for Foraminiferal Research Special Publication 31.

Mackensen, A., Fütterer, D.K., Grobe, H., Schmiedl, G., 1993. Benthic foraminifera assemblages from the eastern South Atlantic Polar Front region between 35 and $57^{\circ} \mathrm{S}$ : distribution ecology and fossilization potential. Mar. Micropaleontol. 22, 33-69.

Mackensen, A., Grobe, H., Kuhn, G., Fütterer, D.K., 1990. Benthic foraminiferal assemblages from the eastern Weddell Sea between $68^{\circ}$ and $73^{\circ} \mathrm{S}$ : distribution ecology and fossilization potential. Mar. Micropaleontol. 16, 241-283.

Margreth, S., Rüggeberg, A., Spezzaferri, S., 2009. Benthic foraminifera as bioindicator for cold-water coral reef ecosystems along the Irish margin. Deep-Sea Res. Pt. I 56, 2216-2234.

Mienis, F., de Stigter, H.C., de Haas, H., van Weering, T.C.E., 2009. Near-bed particle deposition and resuspension in a cold-water coral mound area at the Southwest Rockall Trough margin NE Atlantic. Deep-Sea Res. Pt. I 56, 1026-1038.

Mienis, F., de Stigter, H.C., White, M., Duineveld, G.C.A., de Haas, H., van Weering, T.C.E., 2007. Hydrodynamic controls on carbonate mound development: longterm in-situ seabed BOBO-lander observations and CTD casts at the SW and SE Rockall Trough Margin. Deep-Sea Res. 54, 1655-1674.

Morigi, C., Jorissen, F.J., Gervais, A., Guichard, S., Borsetti, A.M., 2001. Benthic foraminiferal faunas in surface sediments off NW Africa: relationship with the organic flux to the ocean floor. J. Foraminiferal Res. 31, 350-368.

Mortensen, P.B., Hovland, M., Brattegard, T., Farestveit, R., 1995. Deep water bioherms of scleractinian coral Lophelia pertusa (L) at $64^{\circ} \mathrm{N}$ on the Norwegian shelf: structure and associated megafauna. Sarsia 80, 145-158.

Murray, J.W., 2006. Ecology and Applications of Benthic Foraminifera. Cambridge University Press, Cambridge.

Nardelli, M.P., Jorissen, F.J., Pusceddu, A., Morigi, C., Dell'Anno, A., Danovaro, R., de Stigter, H.C., Negri, A., 2010. Living benthic foraminiferal assemblages along a latitudinal transect at $1000 \mathrm{~m}$ depth off the Portuguese margin. Micropaleontology 56, 323-344.

Pancotti, I., 2011. Variazioni longitudinali, batimetriche e biogeografiche di abbondanza, biomassa e diversità della meiofauna a foraminiferi bentonici nel Mediterraneo profondo e Atlantico. Ph.D. Thesis, Universitá Politecnica delle Marche, Italy.

Pusceddu, A., Dell'Anno, A., Fabiano, M., Danovaro, R., 2009. Quantity and bioavailability of sediment organic matter as signatures of benthic trophic status. Mar. Ecol. Prog. Ser. 375, 41-52.

Raes, M., Vanreusel, A., 2005. The metazoan meiofauna associated with a coldwater coral degradation zone in the Porcupine Seabight (NE Atlantic) in: Freiwald, A., Roberts, J.M. (Eds.), Cold-water Corals and Ecosystems, Springer-Verlag, Berlin, Heidelberg, pp. 821-847.

Sabbatini, A., Bonatto, S., Gooday, A.J., Morigi, C., Pancotti, I., Pucci, F., Negri, A. 2010. Modern benthic foraminifers at Northern shallow sites of Adriatic Sea and soft-walled monothalamous taxa: a brief overview. Micropaleontology 56, 359-376.

Sabbatini, A., Morigi, C., Negri, A., Gooday, A.J., 2002. Soft-shelled benthic foraminifera from a hadal site (7800 $\mathrm{m}$ water depth) in the Atacama Trench (SE Pacific): preliminary observations. J. Micropaleontol. 21, 131-135.

Schönfeld, J., 2002. Recent benthic foraminiferal assemblages in deep high-energy environments from the Gulf of Cadiz (Spain). Mar. Micropaleontol. 44 $141-162$.

Schönfeld, J., Dullo, W.C., Pfannkuche, O., Freiwald, A., Rüggeberg, A., Schmidt, S., Weston, J., 2010. Recent benthic foraminiferal assemblages from cold-water coral mounds in the Porcupine Seabight. Facies. doi:10.1007/s10347-0100234-0. 
Shapiro, G.I., Huthnance, J.M., Ivanov, V.V., 2003. Dense water cascading off the continental shelf. J. Geophys. Res., C108. doi:10.1029/2002JC001610.

Suhr, S., Pond, D.W., Gooday, A.J., Smith, C.R., 2003. Selective feeding by benthic foraminifera on phytodetritus on the western Antarctic Peninsula shelf: evidence from fatty acid biomarker analysis. Mar. Ecol. Prog. Ser. 262, 153-162.

White, M., Mohn, C., de Stigter, H.C., Mottram, G., 2005. Deep-water coral development as a function of hydrodynamics and surface water productivity around the submarine banks of the Rockall Trough NE Atlantic. in: Freiwald,
A., Roberts, J.M. (Eds.), Cold-water Corals and Ecosystems, Springer-Verlag, Berlin, Heidelberg, pp. 503-514.

White, M., Murray Roberts, J., van Weering, T., 2007. Do bottom-intensified diurnal tidal currents shape the alignment of carbonate mounds in the NE Atlantic? Geo-Mar. Lett. 27, 391-397.

Zibrowius, H., Taviani, M., 2005. Remarkable sessile fauna associated with deep coral and other calcareous substrates in the Strait of Sicily Mediterranean Sea. in: Freiwald, A., Roberts, J.M. (Eds.), Cold-water Corals and Ecosystems, Springer-Verlag, Berlin, Heidelberg, pp. 807-819. 